\title{
1 Numerical analysis on the Brisbane River plume in Moreton Bay due \\ to Queensland floods 2010-2011
}

\section{Abstract}

\author{
Yingying $\mathrm{Yu}^{1}$, Hong Zhang $^{2}$, Charles Lemckert ${ }^{3}$ \\ Griffith School of Engineering, Griffith University, Queensland, 4222, Australia
}

${ }^{1}$ Corresponding author: y.yu@ griffith.edu.au; Tel.: +617 5552 7511; Fax: +617 55528065

${ }^{2}$ hong.zhang@griffith.edu.au; Tel.: +617 5552 9015; Fax: +617 55528065

${ }^{3}$ c.lemckert@griffith.edu.au; Tel.: +617 5552 8574; Fax: +617 55528065

During the Queensland floods in the Summer of 2010-2011, a flood-driven Brisbane River plume extended into Moreton Bay, Queensland, Australia, and then seaward, travelling in a northward direction. It covered approximately $500 \mathrm{~km}^{2}$. This paper presents a three dimensional hydrodynamic numerical model investigation into the behaviour of the Brisbane River plume. The model was verified by using satellite observations and field measurement data. The present study concludes that the high river discharge was the primary factor determining the plume size and its seaward extensions. A notable finding was that the plume was a bottom-trapped type rather than a buoyant type. Further, the southerly winds were found to have moderately confined the alongshore extension of the plume and caused the plume to mix thoroughly with the ocean water.

Keywords: River discharge, Wind, DHI MIKE3, Hydrodynamic model, Satellite image, Australia, Queensland, Moreton Bay 


\section{$1 \quad 1$ Introduction}

The biological systems of coastal oceans are sensitive to pollution. For this reason, the storm runoff associated with urban activities has been increasingly recognised as a major source of coastal pollution. It is predicted that extreme flooding events will increase in occurrence and severity due to climate change (World Meteorological Organization, 2010). As a consequence, flood-driven plumes will carry an increasing amount of sediment and contaminants, causing further deterioration of coastal systems. In recent years, a number of studies (King et al., 2001; Day et al., 2007; Ou et al., 2009; Shi and Wang, 2009; Yu et al., 2010) have found that river flood-driven plumes have become a significant environmental issue. Therefore, an improved understanding of the dynamic characteristics the flood-driven plume would enhance the predictions for flood impacts on coastal systems and, subsequently, assist with designing and implementing coastal zone management options.

The characteristics of river-forced plumes on Northern Hemisphere coasts have been studied over the last four decades. Garvine (1982), O'Donnell (1986) and Garvine (1987) applied a layer model when investigating river plumes with regard to the Coriolis force in the Northern Hemisphere. They found that the lower and the upper layers tended to flow landward and seaward, respectively. The seaward upper layer flowed to the right of the river mouth, while the landward bottom layer flowed to the left. Avicola and Huq $(2002 ; 2003)$ found that, in addition to the effect of the earth's rotation, river plume development was also impacted by bay geometry and bottom friction. Specifically, in their 2002 study, they observed that a slower and wider river plume tended to occur as the coastal current underwent lateral expansion when the bottom was flat. Conversely, on a sloping bottom, the coastal current might be compressed laterally, in turn, leading to a relatively faster and narrower plume. In the case of deep oceans, however, the bottom friction no longer played a vital role in the dynamic balances (Huq, 2009). An investigation into the effects of the 
1 dimensions of the bay mouth on flow dynamics, by Avicola and Huq (2003) and (Huq, 2009),

2 determined that the Kelvin number, $K$, was the important scaling factor, where $K$ was the

3 ratio of the bay mouth width to the deformation radius of the river plume. The authors found

4 that, for narrow estuaries $(K \leq 1)$, the river plume expanded across the entire width of an

5 estuary. In contrast, for wide estuaries $(K>1)$, dense oceanic water flowed landward on the

6 upshelf side, while the plume water flowed seaward on the downshelf side.

As plumes in nature are rarely unforced, (Fong and Geyer, 2002) were convinced that

8 plume behaviour might be determined by external forces. Further, the joint effects of river

9 discharge and wind on the spatial structure variations of the river plume was discovered

10 earlier by Lentz and Limeburner (1995). The Froude number ( $F=V_{m} / \sqrt{g h_{b}}$, the ratio of the

11 river discharge rate $V_{m}$, to the speed of internal gravity waves $\sqrt{g h_{b}}$ in which $g$ and $h_{b}$

12 represent the gravity acceleration and trapped depth of the plume) was utilised by Chao

13 (1988a) in order to classify different types of river plumes formed under various conditions.

14 The plume was determined to be a bulge shape (supercritical), if the bulge width was less than approximately 1.7 times the width of the alongshore component of the plume (i.e. $F>$ 1.7). In contrast, the seaward extent of the bulge for the subcritical plume (i.e. $F<1.7$ ) was very minor in comparison to the supercritical plume.

It is also hypothesised that the effects of river discharge are more significant on a river plume during flooding than under normal discharge conditions (King et al., 2001), compared to other external forces. Indeed, Marques (2009) emphasised that the amount of fresh water was the principal quantity controlling plume formation and development. The variation of the Eel River (United States) plume's structure during the floods of 1997 and 1998 was reported by Geyer et al. (2000). The flood conditions, which persisted for three days, had peak

24 discharges ranging from 4000 to $12000 \mathrm{~m}^{3} / \mathrm{s}$. They were also accompanied by strong winds 
1 from the southern quadrant. As a result, the plume was restricted to inside the 50-m isobaths;

2 within $7 \mathrm{~km}$ of shore, with northward velocities of $0.5-1 \mathrm{~m} / \mathrm{s}$. Occasional northerly winds

3 attenuated the northward motion of the plume and caused it to spread across the shelf. An

4 investigation of the Mississippi River plume following the intensive rainfall and subsequent

5 flooding, during the spring of 2008, was undertaken by Shi and Wang (2009). They found

6 that the extent of the Mississippi River plume was two times as great as the six-year mean

7 value, due to the greatly increased river discharge flows. The plume area coverage reached a

8 maximum size of $5984 \mathrm{~km}^{2}$ in May 2008. As a consequence of the generation and evolution

9 of the plumes, the concentration of the suspended matter increased from the approximately 20

$10 \mathrm{mg} / \mathrm{l}$ (mega litres) six-year mean value to over $30 \mathrm{mg} / \mathrm{l}$. This $10 \mathrm{mg} / \mathrm{l}$ was expected to have a

11 long-term adverse impact on the coastal ecosystem, although the storm events only lasted a

12 few weeks.

Compared to extent of studies on flood-driven plumes on Northern Hemisphere coasts, very limited investigations into river plumes in response to flood events on Southern Hemisphere coasts have been conducted. Among them, a majority of studies have focused on the river plume in the Great Barrier Reef (GBR), Australia. O'Neill et al. (1992) mapped the 12-day travel of a river plume in the Southern GBR, using a combination of salinity measurements and aerial observations of water colour. King et al. (2001) utilized a survey conducted by Wolanski and Jones (1981) to calibrate and verify a three-dimensional hydrodynamic model of the Burdekin River in flood. Their model results showed some of the flood events that led to an intrusion of the river plume into Reef waters. King et al. (2001) applied this model to investigate the plume into GBR in detail. They found that the plume often touched the bottom in the shallow coastal region depending on wind and discharge rate.

24 As the plume extended offshore, its freshwater content would make it more buoyant than the deeper offshore waters. As a result, the plume would float and generate a stratified water 
1 column in deeper coastal waters. They also concluded that the main driving influences on the

2 fate of the plume water were the discharge volume of the river and the local wind forcing in

3 the far field.

As with the GBR, the Brisbane River, which is the largest river emptying into Moreton Bay, also plays a vital role in ecosystem health (Dennison and Abal, 1999). The variability in its freshwater discharge has the potential to change the hydrographical structure of the Bay, which, in turn, impacts on the marine ecosystem (Eyre et al., 1998; Dennison and Abal, 1999; Ecosystem Health Monitoring Program, 2007). However, the only investigation into the Brisbane River flood-driven plume was conducted by Yu et al. (2011). Their results show that the Brisbane River plume driven by the moderate flood (an average flow rate of $487 \mathrm{~m}^{3} / \mathrm{s}$ ) mainly spread offshore in May 2009. As a consequence of the plume extension, values of the salinity and temperature decreased $4.1 \%$ and $3.5 \%$ offshore (5.5 km east of the river mouth). The correlation coefficient of 0.87 between the plume size and river discharge indicated the river discharge was the dominant factor influencing plume dynamics. (Note that since the current study was restricted to examination of the plume condition in Moreton Bay, the term, Brisbane River plume herewithin refers only to the plume region inside the Bay and correspondingly, the estimation of the plume size only considered the plume area inside the Bay.) Although Yu et al. (2011)'s study investigated the surface extension of the Brisbane River plume following the moderate flood event in 2009 , not only the vertical characteristics of the plume but also the behaviour of the Brisbane River plume under severe flood conditions are still unknown. Therefore, to obtain better understanding, a three-dimensional verified hydrodynamic model was used in the present study to identify the behaviour of the Brisbane River plume in Moreton Bay after extreme flooding in January 2011. The simulation results provide accurate information and assessments on the fate of the flood- 
1 driven plume water that will prove to be a valuable aid in the management of this coastal 2 system.

\section{$3 \quad 2$ Numerical Model}

\section{$4 \quad 2.1 \quad$ Research domain}

Moreton Bay is located in sub-tropical southeast Queensland; it receives freshwater

6 input from the Brisbane River. The bay extends from $153.1^{\circ} \mathrm{E}$ to $153.5^{\circ} \mathrm{E}$ and from $27.05^{\circ} \mathrm{S}$

7 to $27.5^{\circ} \mathrm{S}$, (see Fig. 1), which covers an area of $1523 \mathrm{~km}^{2}$, with the water depth ranging from

82 to $27 \mathrm{~m}$. For the years 1889 to 2006 , the mean annual discharge volume was approximately

$91.65 \times 10^{6} \mathrm{mg} / \mathrm{l}$, the majority of which was river water from the Brisbane River's estuary in

10 the west of Moreton Bay (Queensland Department of Natural Resources Mines and Water,

11 2006). Within the estuary, the Brisbane River discharges fresh water into Moreton Bay's

12 coastal water to form the Brisbane River plume. Additionally two large sewage plants, one

13 located at Oxley Creek (32 km upstream from the river mouth) and the another at Luggage

14 Point (near the river mouth), discharge approximately 900 tonnes of nitrogen into the river

15 per year (Costanzo et al., 2005). As a consequence, during flood events, great volumes of

16 sewage are discharged into the Brisbane River estuary, along with the storm water inputs and

17 agriculture runoff. This input leads to extremely high nutrient concentrations that spread within the plume in Moreton Bay.

\subsection{Model setup}

From late November 2010 to mid-January 2011 the eastern Australian coast

21 experienced an extremely wet period. In south east Queensland, there were six major rain

22 events, leading to widespread flooding of many rivers, and culminating in severe flooding in

23 Brisbane and nearby areas. It is estimated that this flooding event was amongst the most 
1 significant in Australia's recorded history, especially in terms of its extent, damage and

2 severity (National Climate Centre, 2011). One event took place from January $10^{\text {th }}$ to $12^{\text {th }}$,

3 with the heaviest falls in the areas north and west of Brisbane. Further, the majority of the

4 Brisbane River catchment received in excess of $286 \mathrm{~mm}$ of precipitation in three days.

Following this heavy rainfall, the most devastating floods occurred during the second week of January 2011. Consequently, enormous amounts of flood water flowed down the

7 Brisbane River (Fig. 2, a), bringing with it thousands of tonnes of silt and various 8 contaminants, which settled in Moreton Bay. The satellite image from November 2010 shows 9 that waters in the Brisbane River and Moreton Bay were clean (low turbidity), as shown in Fig. 2 (a). However, as the flooding water passed through the mouth of the Brisbane River and into Moreton Bay, in December 2010, the river and bay both displayed elevated turbidity levels (becoming browner in colour) as shown in Fig. 2 (b). To illustrate this further, the observation data show that the salinity at Site 516 (see Fig. 1) was 32.2 psu on $4^{\text {th }}$ Nov and 32.3 psu on $3^{\text {rd }}$ Dec 2010 (before the flood); it then decreased to 19.2 psu on $19^{\text {th }}$ Jan 2011 (7 days after the flood peak discharge). The large reduction in the salinity was therefore attributed to the flood water from the Brisbane River upstream. It also implied that the flood water produced the fresh river plume in the bay. Thus, the Brisbane River plume appeared on the $30^{\text {th }}$ December 2010, then spread significantly on 15 January 2011 , and finally virtually disappeared on the $5^{\text {th }}$ February 2011, respectively.

A 3-D hydrodynamic model, DHI MIKE 3 (DHI Water and Environment, 2011b), was used to simulate the Brisbane river plume evolution over Moreton Bay from the $1^{\text {st }}$ November 2010 to the $31^{\text {st }}$ January 2011. The hydrodynamic module of MIKE 3 is a general numerical modelling system for coastal flows, bathymetry, wind field, bed resistance, and hydrographical boundary conditions. 


\section{$1 \quad 2.3 \quad$ Bathymetry and mesh structure}

The origin of the bathymetry was located at $153.03^{\circ} \mathrm{E}$ and $27.52^{\circ} \mathrm{S}$. The domain to be modelled is presented as a network of three-dimensional elements. The coastline data was provided from the National Oceanic and Atmospheric Administration, while the water depth data was provided by the Marine Safety Queensland. The bathymetry for Moreton Bay shows average depths of $4 \mathrm{~m}$ and $16 \mathrm{~m}$ in the near coast and far shore regions, respectively (Fig. 2, c). In the horizontal domain, the hydrodynamic model geometry consists of a mesh with 1577 elements; the spatial resolution ranges from 200 to 2500 m, as shown in Fig. 2 (c). The fine meshes (ranging from 200 to $500 \mathrm{~m}$ ) were applied in the vicinity of the river mouth and near coastal region to simulate the plume's behaviour. The coarse meshes (ranging from 500 to $2500 \mathrm{~m}$ ) were used in the far-field to save simulation time. In the vertical domain, the variable sigma co-ordinates, formulated by Song and Haidvogel (1994), were applied in the current study (DHI Water and Environment, 2011a). The model was found to be sensitive to the vertical grid resolution. Further, the simulated salinities started to converge when the model had 8 layers. However, to ensure a high resolution at both the surface and the bottom of the bay, the water column was separated into 10 vertical layers. The vertical distribution is given as an example in Fig. 2 (d). The variable sigma coordinate, with 10 layers for the water column, had a depth of $20 \mathrm{~m}$ (as shown in Fig. 2, d) and consequently, permitted high resolutions $(0.5 \mathrm{~m})$ near the surface and bottom. Additionally, the coordinate also maintained a reasonable resolution $(2 \sim 3 \mathrm{~m})$ at mid-depth. In the case of the even shallower region, for instance, the area near the coast (depth $<5 \mathrm{~m}$ ) in Moreton Bay, the resolution at the surface, mid-depth and bottom were approximately $0.5,1 \sim 2$ and $0.5 \mathrm{~m}$, respectively.

Additionally, four open boundaries are highlighted in Fig. 2 (c). The northern and eastern boundaries of the model are marked by NB and EB lines representing the North Passage and South Passage of Moreton Bay, respectively. The southern open boundary starts 
1 at the Cleveland Station $\left(153.29^{\circ} \mathrm{E}, 27.52^{\circ} \mathrm{S}\right)$ and ends at the west border of North

2 Stradbroke Island $\left(153.41^{0} \mathrm{E}, 27.52^{0} \mathrm{~S}\right)$. The fourth open boundary, set at the west of the

3 model mesh, is indicated by a circle (Fig. 2, c) to represent the Brisbane River mouth. In

4 addition to the Brisbane River, the river systems flowing into Moreton Bay include the North

5 and South Pine Rivers, and the Caboolture River. However, in the current study, these have

6 been ignored because of their much smaller discharge compared to the discharge from the

7 Brisbane River.

\subsection{Initial and boundary conditions}

The present study focuses on the flood-driven plume following the 2010-2011 flood events in the Brisbane area, south east Queensland, Australia. The severe floods occurred from December 2010 (National Climate Centre, 2011); hence, a one month spin-up period was added to the model to allow it to reach a dynamic steady state (Overgaard, 2005; Yu et al., 2010). The simulation began on $1^{\text {st }}$ November 2010 and ended on 31 January 2011. The monthly average temperature and salinity data for October 2010 were obtained from WOA98, NOAA (Antonov et al., 2010; Locarnini et al., 2010), and were used for the initial conditions. The predicted tidal heights from the Danish Hydraulic Institute (DHI Water and Environment, 2011a), were applied to three other open boundaries (Northern, Eastern and Southern boundaries).

An hourly river discharge was used at the west open boundary (i.e. Brisbane River mouth); it was provided and derived from field observations by the Department of Environment and Resource Management, Queensland, Australia. The river water discharge was used as the western boundary condition (river inflow). Due to the lack of the bathymetry data on the Brisbane River, the upstream region was excluded from the simulation. Under the 
1 severe flood condition, the flood water rapidly collected sediment, flowed through the river

2 and was well mixed.

\subsection{Calibration and verification}

The time-step of the model was set to a 30-second interval, due to the stability restriction using an explicit scheme. The Smagorinsky formulation, with a constant coefficient of 0.28 , and the log law formulation were applied for the eddy viscosity in horizontal and vertical directions, respectively (DHI Water and Environment, 2011b). The model was calibrated in terms of the hydrodynamic perspective. The bed roughness heights were estimated as $0.07 \mathrm{~cm}$ at the middle of the northern opening $\left(153.263^{\circ} \mathrm{E}, 27.010^{\circ} \mathrm{S}\right)$, $0.52 \mathrm{~cm}$ at the centre of the bay $\left(153.222^{\circ} \mathrm{E}, 27.215^{\circ} \mathrm{S}\right)$ and $1.92 \mathrm{~cm}$ at Deception Bay $\left(153.096^{\circ} \mathrm{E}, 27.153^{\circ} \mathrm{S}\right)$ in Moreton Bay, based on the mean velocities measured for 5 days by You (2005). Hence, a reasonable range of roughness heights from 0.05 to $2 \mathrm{~cm}$, constantly distributed over the entire model domain, were applied in the current calibration process. A uniform roughness height of $0.05 \mathrm{~cm}$ was found to provide the best results in the simulation of this flood event, especially in terms of simulated sea surface temperature, water elevations, and salinity stratifications.

The satellite observations of the sea surface temperatures from NASA's Moderate Resolution Imaging Spectroradiometer (MODIS), at 4-km spatial resolutions, were used for the model verification. The day of flooding, the $20^{\text {th }}$ January 2011, was chosen for the availability of reliable temperature records. The r-squared of 0.9 , between the simulated and satellite observed sea surface temperatures, indicates that the simulated temperature closely matched the satellite observations (Fig. 3, a).

The field measurements of the water level at the Brisbane Bar were obtained from Maritime Safety Queensland; the measurements were compared with the simulated data in 
1 Fig. 3 (b). The r-squared of 0.73 shows agreement between the observed and simulated water

2 levels. As seen in Fig. 3 (b), the simulated water level was slightly lower at high tide rather

3 than was the observed level. These differences may be attributed to the fact that the actual

4 topography of the river mouth was more complicated than the available one. In addition to

5 the sea surface temperature and the surface elevation, the in-situ salinity data, provided by the

6 Ecosystem Health Monitoring Program (EHMP), were available to model verification. The

7 salinity was measured between 9 am and $1 \mathrm{pm}$ (approximately) on the $19^{\text {th }}$ January 2011 , at

8 two sites (see Fig. 1). The model properly produced the salinity stratification, as clearly

9 indicated in Fig. 3 (c). The relatively larger differences of salinity between the simulation and

10 the observation near the surface (for example at site 501) may have been due to the local

11 rainfall, which led to a significant reduction in the surface salinity ${ }^{1}$. Based upon the agreements between the simulated and measured data (surface temperature, surface elevation, and salinity along the depth), the model was verified.

The simulated plume had a similar shape to that of the satellite's observed silt plume, with an area of approximately $460 \mathrm{~km}^{2}$ (Fig. 3, d). In the region $20 \mathrm{~km}$ away from the Brisbane River mouth, the patterns of the simulated sediment-plume appear to be the same as

17 the satellite observations. The shape difference between the simulated and remotely observed 18 plume occurred in the northern bay. This difference can be attributed mainly to the flood 19 water inputs from other coastal rivers, such as the North and South Pine Rivers and the 20 Caboolture River. As the contributions of these rivers to the sediment plume development 21 were not taken into account in the current study, the simulated plume was smaller than the 22 satellite observed plume, as shown in Fig. 3 (d).

\footnotetext{
${ }^{1}$ The local rainfall measurements were not included as an input to the model.
} 


\section{Dynamics of the Brisbane River Plume}

The salinity isohaline of 34.5 (in Practical Salinity Units) was determined to be the front of the Brisbane River plume (referencing the standards applied in Ou et al. (2009)). The measurement was equivalent to the boundary salinity isohaline used in the Great Barrier Reef study by King et al. (2001). Additionally, to investigate the effects of the river discharge and the winds on the evolution of the Brisbane River plume, numerical simulations, with and without the wind forcing, were used.

\subsection{Influence of river discharge}

The investigation took into account the Brisbane River discharge, the Coriolis force, and tide. The discharge data from December 2010 to January 2011 (Fig. 2, a) show that three separate flood events occurred. During this time, the total volume of freshwater discharged into Moreton Bay from the Brisbane River catchment area was $10.5 \mathrm{~km}^{3}$. The tidal heights obtained from Maritime Safety Queensland were applied at the oceanic open boundaries, to represent the effect of the tidal periodic forcing.

In order to evaluate the effects of a river's discharge and the Coriolis force on the plume, the Rossby number, $R_{o}=V_{m} /\left(f L_{m}\right)$, is commonly employed, where $V_{m}$ is the velocity of the river outflow, $f$ is the Coriolis parameter and $L_{m}$ represents the width of the river mouth (Fong and Geyer, 2002). However, as Fong and Geyer (2002) pointed out, the original Rossby number is prognostic since it relies only on the river condition. Hence, to investigate a river plume responding to actual coastal conditions, the original Rossby number was modified for the current study. Therefore, to give due consideration to the effect of the background current $V_{c}$ on the plume development, a modified Rossby number, $R_{m o}=\mid V_{m} /(f$ $\left.L_{m}+V_{c}\right)$, was proposed, where $V_{c}$ is perpendicular to $V_{m}$, and defined as positive if $V_{c}$ is oriented in the north direction. 
2 2010; it resulted in the plume forming and turning left (north) at the mouth. This left turning

3 was due to the effects of the Coriolis force in the Southern Hemisphere. The plume water,

4 driven by the strength of the river's discharge, flowed towards the North Passage at an

5 average rate of $0.3 \mathrm{~m} / \mathrm{s}$ and, as a consequence, the plume moved northward along the coast. It

6 filled all of Bramble Bay, and stretched $21.2 \mathrm{~km}$ to reach Deception Bay (as shown in Fig. 4,

7 a). In addition, the river plume also extended seawards, travelling $4.9 \mathrm{~km}$ to the east of the

8 mouth of the Brisbane River, propagating slightly downstream a distance of $1.6 \mathrm{~km}$. The

9 behaviour of the river water in the vicinity of the river mouth is shown in Fig. 4 (b). A

10 striking feature of the plume's behaviour was that, although the majority of the inflow river

11 water turned left after it was discharged from the mouth, a minority of the flooding water

12 initially flowed straight out into the bay, due to the force of the river discharge, and then

13 turned left.

At the end of the first discharge event, the Brisbane River plume covered approximated $384 \mathrm{~km}^{2}$ in Moreton Bay. Afterwards, the plume water gradually mixed with the coastal water and was diluted to a size of $298 \mathrm{~km}^{2}$ with the decreasing river inflow. The second 17 discharge peak, with an average rate of $5104 \mathrm{~m}^{3} / \mathrm{s}$, occurred on 29 December 2010 . This 18 flood event subsided after two days, and the plume size increased back to $327 \mathrm{~km}^{2}$.

The third peak river inflow with the highest flood discharge $\left(17933 \mathrm{~m}^{3} / \mathrm{s}\right)$ occurred on 20 the $12^{\text {th }}$ January 2011 . The salinity contour and surface velocity fields at midnight that day 21 are presented in Fig. 4 (c) and (d). As can be seen in these two figures, the plume water to the north had already passed through the North Passage. Due to the estimation of plume size in this study only considered the plume region inside Moreton Bay, therefore, the plume size 24 after 12 January was underestimated to some extent. 
1 Following the flood runoff, the plume spread over Moreton Bay and covered an area of

$2519 \mathrm{~km}^{2}$. Clearly the inflow river water divided into two branches after it was discharged

3 from the mouth. One branch of the plume water extended north at $1.4 \mathrm{~m} / \mathrm{s}$ due to the effect of 4 the Coriolis force; the other branch went in a north easterly direction (seawards), at a rate of 2 $5 \mathrm{~m} / \mathrm{s}$, being perpendicular to the line of the river mouth. The comparison of the plume 6 behaviour, following these three peak discharges, implies that the third peak discharge was 7 strong enough to produce the significant seawards movement of the Brisbane River plume.

Further, the plume evolution was estimated using the deformation radius of the river 9 plume, $R$, and the internal Kelvin number, $K$, which were used in previous studies (Avicola and Huq, 2002; Huq, 2009), as follows:

$$
\begin{gathered}
R=\left(2 Q g_{r}^{\prime}\right)^{1 / 4} / f^{3 / 4} \\
K=\frac{L_{m}}{R}
\end{gathered}
$$

where $Q$ is the river discharge; $g_{r}^{\prime}$ represents the reduction gravity calculated from the value of the maximum density anomaly at the source; and $L_{m}$ is the width of the river mouth.

The variation of the deformation radius of the plume with the river discharge (Fig. 5, a)

14 shows the effects of the river discharge (along with the Coriolis force) on the plume 15 deformation. The larger value of $R$, arising from the higher river discharge, and the relatively smaller value of $L_{m}$, due to the narrow Brisbane River mouth, generally resulted in $K$ values of less than 0.8 . For $K<1$ outflows, the buoyant water flowed out over the entire width of the river mouth; similar results were found by Avicola and Huq (2002). Also, the modified Rossby number and the background current during the flood period, shown in Fig. 5 (b), 20 clearly shows that the $R_{m o}$, with the $f L_{m} \approx 0.053 \mathrm{~m} / \mathrm{s}$ at the Brisbane River mouth, was closer to 10 after the first peak discharges, and increased to 35 after the second peak discharges. The 
1 higher $R_{m o}$ indicates that a strong outflow was created by the momentum of the river 2 discharge.

In addition to the effect of the river discharge, the Rossby number also depends on the background current. Thus, if the river discharge is relatively low, then the larger background currents $(>0.2 \mathrm{~m} / \mathrm{s})$ lead to a smaller $R_{m o}(<=1)$. When the three largest $R_{m o}$ occurred after peak discharges, the background current was negative (towards the south), which was in the opposite direction to that of the plume's alongshore transport (i.e. towards the north). As a consequence, the alongshore transport of the plume became relatively smaller and weaker, while the bulge component of the plume developed circularly near the river mouth. These results are in accord with Fong and Geyer (2002) conclusions. Although the model presented here did not include the influence of the wind, the ratio $\left|V_{c} / f L_{m}\right|$ can be as large as 5, suggesting the variation of the $R_{m o}$ was highly sensitive to the condition of the background current; that is, the background current was expected to strongly affect plume development when the river is located at a low-latitude with a narrow entrance.

Four specific points (P1, P2, P3 and P4, as marked in Fig. 1) were selected to investigate the vertical distribution, and the temporal evolution, of the plume. Transect 1 (T1) was located $3 \mathrm{~km}$ north of the river mouth, starting at P1 and ending at P2; and Transect 2 (T2) was located between P3 and P4, in front of the Brisbane River mouth. Fig. 6 (a) and (b) display typical salinity profiles along the two transects, which show that the plume water, both the seawards and alongshore components, were completely mixed without stratification. As shown in Fig. 6 (a), the denser water was on the landward side, while the lighter water was on the offshore side, across Transect 1. This separation occurred, chiefly, from the northward expansion of the plume bulge (as shown in Fig. 4, c). Thus, the freshest plume bulge off the river mouth, with a salinity isohaline of 25.5 pus, expanded towards the north and passed through P2. As a result, the salinity around P2 continually decreased. In contrast, 
1 the salinity in P1 was not affected by the freshest bulge, as the areas were much closer to the 2 coast and was away from the freshest plume bulge. Consequently, at the Transect 1, the 3 heavier water was on the landward side and the lighter water was on the seaward side.

In addition to the vertical salinity distribution, the velocity profiles can also be seen in

5 Fig. 6 (c) and (d). In terms of the velocity field for Transect 1, as the plume water flowed 6 northward in a horizontal direction, the plume water moved onshore in a vertical direction, 7 with slower velocities occurring with the high tide. In the presence of the flood tide, the 8 velocities of the outside and inside layers were $0.04 \mathrm{~m} / \mathrm{s}$ and $0.048 \mathrm{~m} / \mathrm{s}$, respectively. The 9 velocity field of Transect 2, as shown in Fig. 6 (d), had different conditions from those of Transect 1 . There were two distinct sets of velocity contours across Transect 2 (T2). The left set of the velocity contours (Fig. $6 \mathrm{~d}, \mathrm{~T} 2$ ) arose from the branch of the river discharge, which was towards the north (Fig. 4, b and c). Hence, its velocity was at the higher rate of $1 \mathrm{~m} / \mathrm{s}$ and the plume water tended to lift up in the vertical direction. At the right, the flow was augmented by another branch of the river discharge, which was moved seawards (Fig. 4, b and c).

Tides also impacted upon the plume (Fig. 6, e), with variations of the Brisbane River water level and velocity being influenced at P4 throughout the tidal cycle. During the ebb tide, the cross-shore velocity at P4 increased, while it decreased during the flood tide. As a result, the tidal wave and the cross-shore velocity were principally in quadrature. In contrast, the alongshore velocity at P4 did not experience large fluctuations, except when it had a higher velocity, due to the peak river discharge in the first six hours. As described above, the flooding flow at the river mouth generated significant northward and seaward velocity fields.

23 Therefore, the tidal influence was significant over the seaward expansion of the plume, but 24 less so on the northward component. 
From the above analysis it can be seen that the river discharge plays a vital role in the

2 behaviour of the plume water. Importantly, the higher river discharge was the primary factor

3 determining the size, evolution and dynamic of the river plume. Further, the tidal forces

4 weakened the seawards movement of the plume and provided energy for the plume water to

5 mix with the oceanic water.

\section{$6 \quad 3.2 \quad$ Influence of wind}

Various studies (e.g. Chao, 1988b; Cheng and Casulli, 2003; Fong and Geyer, 1997;

8 King et al., 2001; Ou et al., 2009) have shown that plume development is highly correlated to

9 wind conditions. In their studies, Whitney and Garvine (2005), and Ou et al. (2009) applied

10 the wind strength index to estimate the wind impact on plume development. The wind

11 strength index, $I_{w}$, is defined as:

$$
\begin{gathered}
I_{w}=\frac{u_{\text {wind }}}{u_{d s}} \\
\text { where, } u_{\text {wind }}=\sqrt{\frac{\rho_{a}}{\rho} \frac{C_{10}}{C_{D a}}} u_{10} \\
u_{d s}=\frac{1}{K}\left(2 g_{r}{ }^{\prime} Q f\right)^{1 / 4}
\end{gathered}
$$

12 where $u_{\text {wind }}$ is the alongshore current velocity generated by the wind, and $u_{d s}$ is the alongshore

13 current velocity driven by the river runoff. Thus, $u_{\text {wind }}$ and $u_{d s}$ can be estimated using 14 Equations (4) and (5), where $U_{10}$ is the wind velocity at $10 \mathrm{~m}$ height; $C_{10}=1.2 \times 10^{-3}$ is the 15 surface drag coefficient; $C_{D a}=2 \times 10^{-3}$ is the depth averaged drag coefficient; and $\rho_{a}$, and $\rho$ are the densities of the air and the coastal water, respectively. When $\left|I_{w}\right|>1$, the wind force is dominant. If taking the southward flow direction as positive, then $I_{w}$ is positive during the north wind flow, or negative during the south wind.

Using the above specifications, the actual wind conditions were introduced into the simulation to closely represent the actual coastal conditions. The wind data were collected at 
1 the Brisbane Bar (as marked in Fig. 1). This time-dependent wind data were applied in the

2 model over the entire study area. Fig. 7 (a) shows the wind speed and its direction. As can be

3 seen Fig. 7 (a), during the flooding event from December 2010 to January 2011, the south

4 south-easterly (SSE) winds dominated Moreton Bay most of the time, with an average speed

5 of $18 \mathrm{~m} / \mathrm{s}$. When the peak discharge occurred on 12 January, the easterly wind blew over

6 Moreton Bay at a maximum speed of $25 \mathrm{~m} / \mathrm{s}$.

Further, it was found that the relative size of the Brisbane River plume during the flood was influenced by the winds. Fig. 7 (b) shows the variations in the plume size with and

9 without wind blowing. Generally, the plume with the influence of the wind covered a smaller region of Moreton Bay than the plume developed without wind impacts. A similar result was observed by Fong and Geyer (1997; 2001), Zhang and Chan (2003), and Whitney and

Garvine (2005). In addition, the effects of the southerly winds on the plume were present in the vertical direction. Fig. 7 (c) shows the vertical distribution of the velocity across the two transects on the $12^{\text {th }}$ January, 2011. These winds moved the surface water towards the coast, while the subsurface water sank along Transect 1 (Fig. 7, c, T1). Although the pattern of the velocity of T2 in Fig. 7 (c) was similar to that in Fig. 6 (e), the plume water flowed seawards at a slower rate. It is likely that this occurred because of the positive effect of the river discharge on the seawards movement of the plume, which was more dominant than the negative effect of the southerly winds. The wind strength index, $I_{w}$, equalled $-0.49,-0.75$ and 0.31 on January $11^{\text {th }}, 12^{\text {th }}$ and $13^{\text {th }}, 2011$, respectively. The values of $\left|I_{w}\right|$ approach $O(1)$; thus, although the winds were less dominant than the river discharge during this period of flooding, the effects of the wind were potentially still significant.

Simple momentum balances have also been used for the dynamic interpretation of the 24 numerical model solutions (Masse and Murthy, 1992). Applying the Boussinesq 
1 approximation, the horizontal momentum for the cross-shore $(x-)$ and alongshore $(y-)$

2 components at four specific points, P1, P2, P3 and P4, as marked in Fig. 1, were estimated.

3 These four sites were selected for two reasons: (1) They were within the plume region during

4 the entire period of plume development in Moreton Bay; (2) The four points were located at

5 four different characteristic sites. In detail, P1 is close to the coast but away from the river

6 mouth; P2 is not only away from the river mouth also away from the coast; P3 is close to the

7 river mouth and also near the coast; but P4 is further seaward Therefore, the momentum

8 conditions at these four points would clearly quantify the influences of river discharge, the

9 Coriolis force and wind on the plume at different characteristic sites. Fig. 8 and 9 illustrate

10 the convection, Coriolis and wind stress terms in the horizontal momentum balance on 12

11 January 2011. Further, Fig. 8 shows that the Coriolis acceleration dominated the cross-shore balance at P2, P3 and P4; however, the wind stress was more significant in the region near

13 the coast at P1.

14 Similar results were found for the alongshore momentum balances at P1 and P2 (in Fig.

15 9); that is, the Coriolis acceleration and the wind stress were the principal influences at P1 16 and P2, respectively. In relation to P3 and P4, which were closer to the river mouth, their 17 alongshore convections were clearly dominant over the other two factors of Coriolis and wind. Additionally, the wind stresses were negative along the shore, but were positive across the shore, as shown in Fig. 8 and Fig. 9. This result confirmed that the southerly wind that

20 prevailed on the $12^{\text {th }}$ January restricted the seaward extension of the river plume, but drove 21 the northward spread component. In summary, the developments of the river plume were 22 determined by the joint contributions of the wind stress, the Coriolis force, and the river 23 discharge. When the plume formed near the river mouth, the river discharge strongly drove it towards the north. The Coriolis force then became the main influencing factor once the plume 
1 moved north from the river mouth. As the plume approached the coast, its movement

2 depended more upon the wind conditions.

\section{The Evolution of the Brisbane River Plume}

Within this study, it is important to understand the evolution and characteristics of the

5 flood-driven plume. The evolution of the Brisbane River plume, during the period of the 6 largest flood peak, is exhibited below.

\section{$7 \quad 4.1$ Horizontal characteristics}

Following previous studies (Chao, 1988a; 1988b; Fong and Geyer, 2002; Ou et al.,

9 2009), the non-dimensional parameters, $\lambda$ and $\lambda_{i}$ were also used to classify the river plume 10 structure:

$$
\begin{aligned}
& \lambda=\frac{L}{L_{n}} \\
& \lambda_{i}=\frac{L_{u}}{L_{d}}
\end{aligned}
$$

11 where $L$ and $L_{n}$ represent the width of the bulge area and upstream component of the plume, respectively, and $L_{u}$ is defined as the length of the upper part of the bulge, while $L_{d}$ describes the length of the lower part of the bulge, as shown in Fig. 10 (a). For Cases with $\lambda<1.7$, the river plumes were typically subcritical, and spread in the alongshore direction more than seawards direction (Chao, 1988a; 1988b). Similarly to the findings in Ou et al. (2009), the river plumes were classified as upstream seawards plumes when $\lambda_{i}>1$, and as downstream seawards plumes when $\lambda_{i}<1$.

Fig. 10 (b) depicts the variations of these two non-dimensional parameters of the plume in January 2011. The $\lambda_{i}$, which was larger than 10 at all times, indicated that the northward component of the Brisbane River plume was more dominated than the southward

21 component during the period of the flood event. By the $31^{\text {st }}$ January, the plume stretched 
1 more than $20 \mathrm{~km}$ northward away from the river mouth, while it travelled only $1.6 \mathrm{~km}$ along

2 the southward coast. A significant decrease of $\lambda_{i}$ occurred from the $12^{\text {th }}$ to $17^{\text {th }}$ January.

3 Further, the simulation results indicated that the plume continuously extended northward and

4 passed through the North Passage, while the length of the component of the plume along the

5 southward coast experienced an increase from $1.5 \mathrm{~km}$ to $2.3 \mathrm{~km}$, which resulted in a marked

6 decrease of $\lambda_{i}$. Such variation may be related to occurrence of the severe flood on the $12^{\text {th }}$

7 January. Additionally, a large amount of the river water gathered around the river mouth,

8 with a fraction of the river water propagating along the south coast (see $\lambda_{i}$, Fig. 10, b for a

9 display in the variation of $\lambda$ ). As suggested by previous study (Yu et al., 2011), the river

10 runoff through the Brisbane River mouth always formed a bulge plume at the entrance of the

11 estuary, with the $\lambda>1.7$ during the moderate flood event (at an average rate of $487 \mathrm{~m}^{3} / \mathrm{s}$ ) in

12 May 2009. However, following the flooding in January 2011, the $\lambda$ was generally less than 1.7,

13 which indicates that the plume mainly spread in the alongshore direction more than the

14 seawards direction, and the plume bulge in front of the river mouth was not dominant during

15 the period of the entire evolution of the plume. The $\lambda$ was greater than 1.7 only on January 12 ,

1613 and 14 , when the highest flood discharge $\left(17933 \mathrm{~m}^{3} / \mathrm{s}\right)$ occurred. Although the plume

17 retained a similar shape before and after this peak discharge occurrence, the width of the

18 bulge component of the plume increased by $91 \%$, from $5.5 \mathrm{~km}$ to $10.5 \mathrm{~km}$. In contrast, the

19 width of the northern component of the plume only increased by $23 \%$, from $5 \mathrm{~km}$ to $6.15 \mathrm{~km}$.

20 The significant increase of the bulge component might be attributed to extremely large

21 amount of flooding water that entered the bay area and accumulated in the vicinity of the river mouth over a short period. Overall, the Brisbane River plume in January 2011 was

23 generally defined as a diffusive-subcritical plume, characterised by high eddy diffuse

24 viscosity, according to the classification of the river plume proposed by Chao (1988a), and

25 Kourafalou and Lee (1999). That is, the width of the alongshore component of the plume was 
1 greater than the width of the plume bulge, while the plume was development in a shallow

2 area and driven by high flood discharge.

\subsection{Vertical characteristics}

Fig. $11(\mathrm{a}, \mathrm{b}, \mathrm{c}$ and $\mathrm{d})$ show the vertical profiles of the salinity along Transect 2 on December 1, 2, and 3, 2010, and January 13, 2011. The figures clearly indicate that the water was visibly stratified, with the low-salinity water floating on top of the high salinity water, along Transect 2, on 1 December 2010. However, due to the growth of the river discharge, the salinity stratification became weak, as shown, for example, in the plume in Fig. 11 (d). These findings are consistent with those of King et al. (2001) who found that the plume often touched the bottom in the shallow coastal regions where the depth was less than $15 \mathrm{~m}$. The buoyant layer scaling $h_{b}=\left(2 Q f / g_{r}^{\prime}\right)^{1 / 2}$ provided by Yankovsky and Chapman (1997) was used to estimate the depth of the Brisbane river plumes in the current study. It yielded a trapping depth of the Brisbane River plume that ranged from $8 \mathrm{~m}$ to $24 \mathrm{~m}$, which was larger than the water depth at the Brisbane River mouth of $4.5 \mathrm{~m}$. The study also confirmed that a pure surface-advected plume was difficult to achieve in the vicinity of the Brisbane River mouth, due to the shallow water depth $(<15 \mathrm{~m})$.

Further, the small-scale stratification only took place at the outmost plume layer in the deeper water area. The plume at the cross-section, which was $5 \mathrm{~km}$ seaward from the Transect 2, was weakly stratified, as shown in Fig. 11 (e) and (f). Thus, it appears that the less saline water floated above the more saline water. Note that water depth for this crosssection was greater than $15 \mathrm{~m}$; hence, it can be inferred that the bathymetry was another factor influencing the stratification within the plume. 


\section{$1 \quad 4.3$ Plume development and dispersion}

According to the simulations and satellite observations of the 2010-2011 Brisbane River flood event, the bulge of the plume was, typically, 5-6 $\mathrm{km}$ wide, and reached a maximum width of $14 \mathrm{~km}$ after the third peak discharge. The extremely large river discharge resulted directly in the plume's extension seawards in front of the river mouth, as well as along the northward coast. The plume reached the northernmost side of the study area (see Fig. 3, d and Fig. 4, c), where it met the Coral Sea and, thereby, threatened the oceanic environment. As a consequence of the flood-driven plume, the salinity of the coastal water decreased significantly. The values of the depth-average salinity were estimated to decline by $29.4 \%$ (from 32.3 to $22.8 \mathrm{psu}$ ) along the north-west coast, with an affected distance of $24 \mathrm{~km}$ north of the river mouth.

A clear correlation of the plume area and river discharge can be seen in Fig. 7 (b); thus, a lag existed between them. Using cross-correlation analysis, the lag between the plume region and river discharge was estimated at 2 days. To set these results in context, the characteristics of the several extreme flood-driven plumes of recent years are listed in Table 1. It can be concluded, therefore, that the river discharge in January 2011 was 10 times as great as in May 2009, resulting in a 27 times larger plume region. Further, when the flood ceased in May 2009, the plume coverage immediately became smaller (Yu et al., 2011). In contrast, in January 2011, there was a substantial delay in the occurrence of the river plume dissipation after the decline of the river discharge. This effect was due to the extreme flooding event in which the discharge was an enormous amount of river water flowing into the coastal region; hence, it took a much longer time to disperse such large volumes. In January 1981, when there was a major flood event, the plume on the Great Barrier Reef (King et al., 2001) also did not disappear immediately after the flooding.

The dispersion time of a plume can be defined as: 


$$
T=\frac{\int_{t_{1}}^{t_{2}} Q d t}{L_{\text {avg }} \times D_{\text {avg }} \times V_{\text {depth }}}
$$

1 where $t$ is the time, $t_{1}$ and $t_{2}$ are the starting and finishing times of the flooding event, $L_{\text {avg }}$

2 indicates the average width of the plume, $D_{a v g}$ is the average depth of the plume, and $V_{\text {depth }}$ 3 represents the depth-average velocity at the front boundary of the plume, while $Q$ is the river 4 discharge.

5 After the last peak discharge occurred on the $12^{\text {th }}$ January 2011 , the outermost edge of 6 the Brisbane River plume (represented by a salinity isohaline of 34.5 psu, as shown in Fig. 4, 7 c) was located in the Central Bay and extended to the North Passage. With a large reduction 8 in the flood discharge from 17 January, the plume began to fade away. Using Equation (8), 9 the Brisbane River plume, in the 2010-2011 flood event, was determined to take approximately 20 days to become completely diluted after the peak discharge. Also, as shown in the Fig. 2 (b), the sediment plume was generally diminished, and Moreton Bay was almost clear again, by 5 February 2011. This finding is in accord with the prediction of Equation (8).

\section{Conclusions}

The dynamics of the flood-driven Brisbane River plume, resulting from the Queensland floods of 2010-2011, was studied using a three-dimensional numerical model. Both the river discharge and the winds were progressively introduced into the model in order to determine the respective influence of each on the plume and its dynamic characteristics. extremely large discharge strength. The model simulations demonstrate that the Brisbane

20 River plume flowed along the northward coast (upstream) for a distance of about $30 \mathrm{~km}$, and 21 flowed seawards for a maximum width of approximately $14 \mathrm{~km}$. The Brisbane River plume, typically, reached the bottom in shallower coastal waters. Also, there was a typical estuarine 
1 circulation with the seaward current in the upper layer and the landward current in the lower

2 layer. In deeper water, the outmost layer of the Brisbane River plume tended to be less dense

3 than the surrounding coastal waters. The plume was observed to be 15 to $25 \mathrm{~m}$ thick. The

4 results also show that the river discharge was the dominant factor in determining the

5 development of the Brisbane River plume. It drove the river plume along the north coast and

6 seawards against the south winds.

7 The analysis, using the modified Rossby number $R_{m o}$, suggests that the river plume was 8 more likely to be affected by the background current when the river is located at a lower

9 latitude, with narrower river outflows. In addition to the effects of the background current, 10 the developments in the river plume were determined by the joint contributions of wind stress,

11 the Coriolis force, and the river discharge. Near the river mouth, the momentum of the river

12 discharge drove it strongly towards the north (the Southern Hemisphere), particularly during

13 large flood events. The Coriolis force then became the main influencing factor once the 14 plume moved north from the river mouth. As the plume approached the coast, its movement 15 depended more upon the wind conditions.

16 While plume trajectories can be said to be complex and event-driven, the present study 17 has clarified a number of aspects related to the dynamics of flood-driven plumes, specifically

18 the river discharge and the wind. Importantly, it has shown that there is a significant decline 19 in the quality of coastal waters following severe flooding. 


\section{References}

Antonov, J.I., Seidov, D., Boyer, T.P., Locarnini, R.A., Mishonov, A.V., Garcia, H.E., Baranova, O.K., Zweng, M.M., Johnson, D.R., 2010. Salinity, World Ocean Atlas 2009 1, 184.

Avicola, G., Huq, P., 2002. Scaling analysis for the interaction between a buoyant coastal current and the continental shelf: Experiments and observations, Journal of Physical Oceanography 32, 3233-3248.

Avicola, G., Huq, P., 2003. The role of outflow geometry in the formation of the recirculating bulge region in coastal buoyant outlfows, Journal of Marine Research 61, 411-434.

Chao, S.Y., 1988a. River-forced estuarine plumes, Journal of Physical Oceanography 18, 7288.

Chao, S.Y., 1988b. Wind-driven motion of estuarine plumes, Journal of Physical Oceanography 18, 1144-1166.

Costanzo, S.D., Udy, J., Longstaff, B., Jones, A., 2005. Using nitrogen stable isotope rations $\left(\delta^{15}\right)$ of macroalgae to determine the effectiveness of sewage upgrades: changes in the extent of sewage plumes over four years in Moreton Bay, Australia, Marine Pollution Bulletin 51, 212-217.

Day, J.W., Boesch, D.F., Clairain, E.J., Kemp, G.P., Laska, S.B., Mitsch, W.J., Orth, K., Mashriqui, H., Reed, D.J., Shabman, L., Simenstad, C.A., Streever, B.J., Twilley, R.R., Watson, C.C., Wells, J.T., Whigham, D.F., 2007. Restoration of the Mississippi Delta: Lessons from Hurricanes Katrina and Rita, Science 315, 1679-1684.

Dennison, W.C., Abal, E.G., 1999. Moreton Bay study: a scientific basis for the Healthy Waterways Campaign, South East Queensland Regional Water Quality Management Strategy

DHI Water and Environment, 2011a. MIKE 21 \& MIKE 3 FlOW MODEL FM, Hydrodynamic and transport module scientifc documentation, DHI

DHI Water and Environment 2011b. User guide of MIKE3: Estuarine and coastal hydraulics and oceanography, Hydrodynamic module. Scientific documentation.

Ecosystem Health Monitoring Program, 2007. Ecosystem Health Monitoring Program 200506 Annual Technical Report, South East Queensland Healthy Waterways Partnership

Eyre, B., Hossain, S., McKee, L., 1998. A suspended sediment budget for the modified subtropical Brisbane River estuary, Australia, Estuarine, Coastal and Shelf Science 47, 513-522.

Fong, D.A., Geyer, W.R., 1997. The wind-forced response on a buoyant coastal current: observations of the western Gulf of Maine plume, Journal of Marine Systems 12, 6981.

Fong, D.A., Geyer, W.R., 2001. Response of a river plume during an upwelling favorable wind event, Journal of Geophysical Research 106, 1067-1084.

Fong, D.A., Geyer, W.R., 2002. The alongshore transport of freshwater in a surface-trapped river plume, Journal of Physical Oceanography 32, 957-972.

Garvine, R.W., 1982. A steady state model for buoyant surface plume hydrodynamics in coastal waters, Tellus 34, 293-306.

Garvine, R.W., 1987. Estuary plumes and fronts in shelf waters: A layer model, Journal of Physical Oceanography 17, 1877-1896.

Geyer, W.R., Hill, P., Milligan, T., Traykovski, P., 2000. The structure of the Eel River plume during floods, Continental Shelf Research 20, 2067-2093.

Huq, P., 2009. The role of Kelvin Number on bulge formation from estuarine buoyant outflows, Estuarines and Coasts 32, 709-719. 
King, B., McAllister, F., Wolanski, E., Done, T., Spagnol, S., 2001. River plume dynamics in the central Great Barrier Reef. In Wolanski, E. (Eds.), Oceanographic Processes of Coral Reefs: Physical and Biological Links in the Great Barrier Reef. CRC Press LLC, New York, Washington, D.C., pp. 145-159.

Kourafalou, V.H., Lee, T.N., 1999. The fate of river discharge on the continental shelf1, modeling the river plume and the inner shelf coastal current, Journal of Geophysical Research 101, 3415-3434.

Lentz, S.J., Limeburner, R., 1995. The Amazon River plume during AMASSEDS: spatial characteristics and salinity variability, Journal of Geophysical Research, Oceans 100, 2355-2375.

Locarnini, R.A., Mishonov, A.V., Antonov, J.I., Boyer, T.P., Garcia, H.E., Baranova, O.K., Zweng, M.M., Johnson, D.R., 2010. World Ocean Atlas 2009, Volume 1: Temperature, $184 \mathrm{pp}$.

Marques, W.C., Fernandes, E.H., Monteiro, I.O., Moller, O.O., 2009. Numerical modeling of the Patos Lagoon coastal plume, Brazil, Continental Shelf Research 29, 556-571.

Masse, A.K., Murthy, C.R., 1992. Analysis of the Niagara River plume dynamics, Journal of Geophysical Research 97, 2403-2420.

National Climate Centre 2011. Frequent heavy rain events in late 2010/early 2011 lead to widespread flooding across eastern Asutralia. Special climate statement 24. Bureau of Meteorology.

O'Donnell, J. 1986. A numerical model of the dynamics of buoyant discharges. College of Marine Studies. University of Delaware.

O'Neill, J.P., Byron, G.T., Wright, S.C. 1992. Some physical characteristics and movment of 1991 Fitzroy River flood plume. in Byron, G.T. (Ed.) Workshop on the Impacts of Flooding. Great Barrier Reef Marine Park Authority, Townsville.

Ou, S., Zhang, H., Wang, D.X., 2009. Dynamics of the buoyant plume off the Pearl River Estuary in summer, Environmental Fluid Mechanics 9, 471-492.

Overgaard, J. 2005. Energy-based Land-Surface Modelling: New Opportunities in Integrated Hydrological Modelling. Environment and Resources DTU. Technical University of Denmark.

Queensland Department of Natural Resources Mines and Water, 2006. Moreton draft water resource plan overview report and draft plan : incorporating the catchments of : Brisbane River, Pine River, Caboolture River, Cabbage Tree Creek, Pumicestone Creeks / prepared by Water Planning Group and Water Services (South East Region), Department of Natural Resources, Mines and Water.,

Shi, W., Wang, M., 2009. Satellite observation of flood-driven Mississippi River plume in the spring of 2008, Geophysical Research Letters 36.

Song, Y., Haidvogel, D., 1994. A semi-implicit ocean circulation model using a generalized topography-following coordinate system, Journal of Computational Physics 115, 228244.

Whitney, M.M., Garvine, R.W., 2005. Wind influence on a coastal buoyant outflow, Journal of Geophysical Research 110.

Wolanski, E., Jones, M., 1981. Physical properties of Great BarrierReef lagoon waters near Townsville I: Effects of Burdekin River floods, Australia Journal of Marine and Freshwater Research 32, 505-519.

World Meteorological Organization 2010. The WMO annual statement on the status of the global climate 2009.

Yankovsky, A.E., Chapman, D.C., 1997. A simple theory for the fate of buoyant coastal discharges, Journal of Physical Oceanography 27, 1386-1401. 
You, Z.J., 2005. Estimation of bed roughness from mean velocities measured at two levels near the seabed, Continental Shelf Research 25, 1043-1051.

Yu, Y., Zhang, H., Lemckert, C.J., 2010. Numerical study on a river plumes on a Southern Hemisphere coast, Proceedings of the 20th International Offshore and Polar Engineering Conference 1, 959-962.

Yu, Y., Zhang, H., Lemckert, C.J., 2011. The response of the river plume to the flooding in Moreton Bay, Australia, Journal of Coastal Research, Szczecin, Poland, pp. 12141218.

Zhang, H., Chan, E.S., 2003. Modeling of the turbulence in the water column under breaking wind waves, Journal of Oceanography 59, 331-341. 


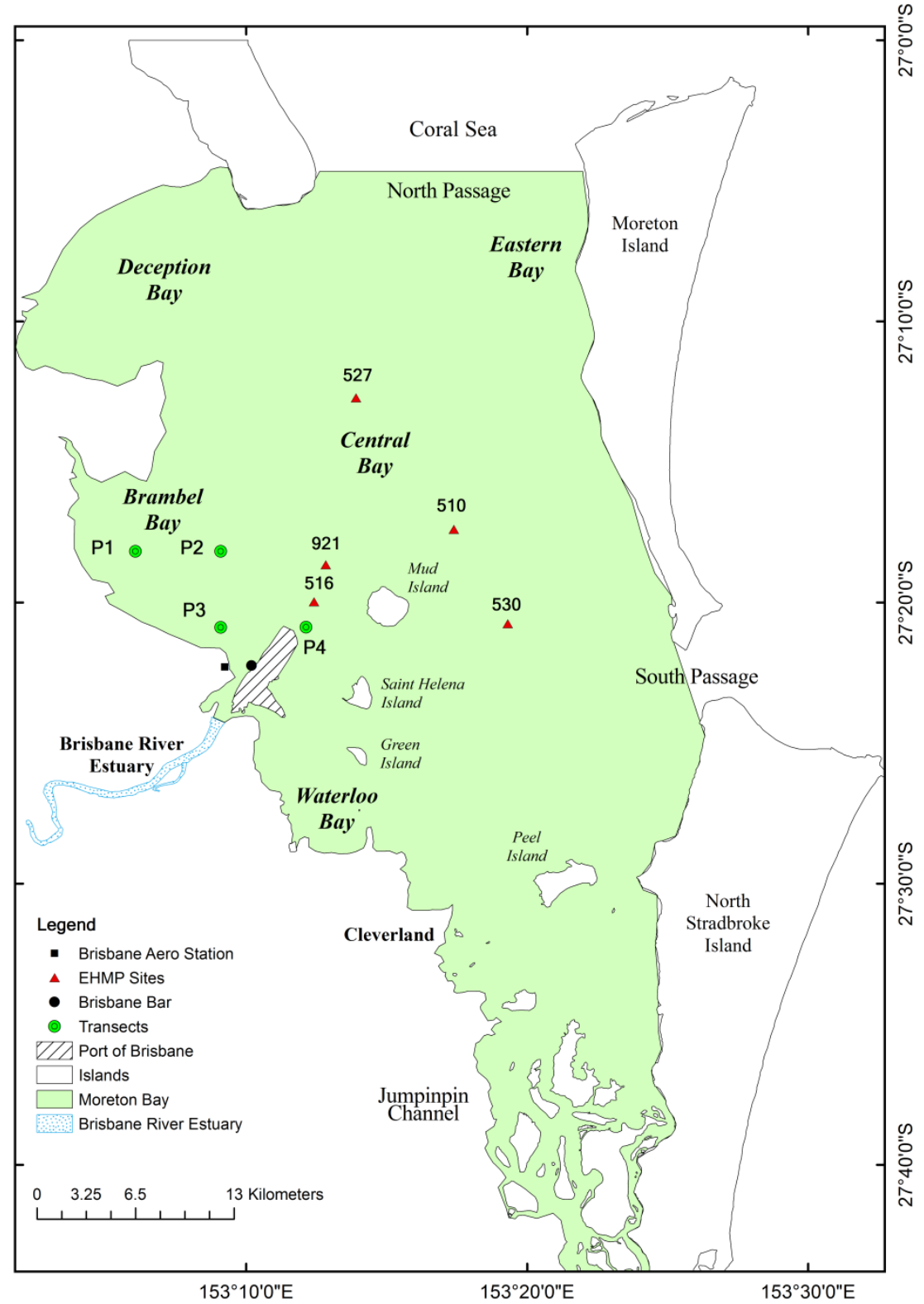

Fig. 1. Location map of study site (Data Source: Geoscience Australia). Within Moreton Bay are the smaller bays of Eastern Bay, Deception Bay, Bramble Bay, Central Bay and Waterloo Bay. Brisbane Bar, Brisbane Aero Station and observation sites of Healthy Waterways Organisation are all marked out. There are two transects: Transect 1 starts at P1 and ends at P2, Transect 2 starts at P3 and ends at P4. P1, P2, P3 and P4 are located at (51000, 6980000), (51500, $6980000),(51500,6975000)$, and $(52000,6975000)$ in the Map Projection, respectively. 


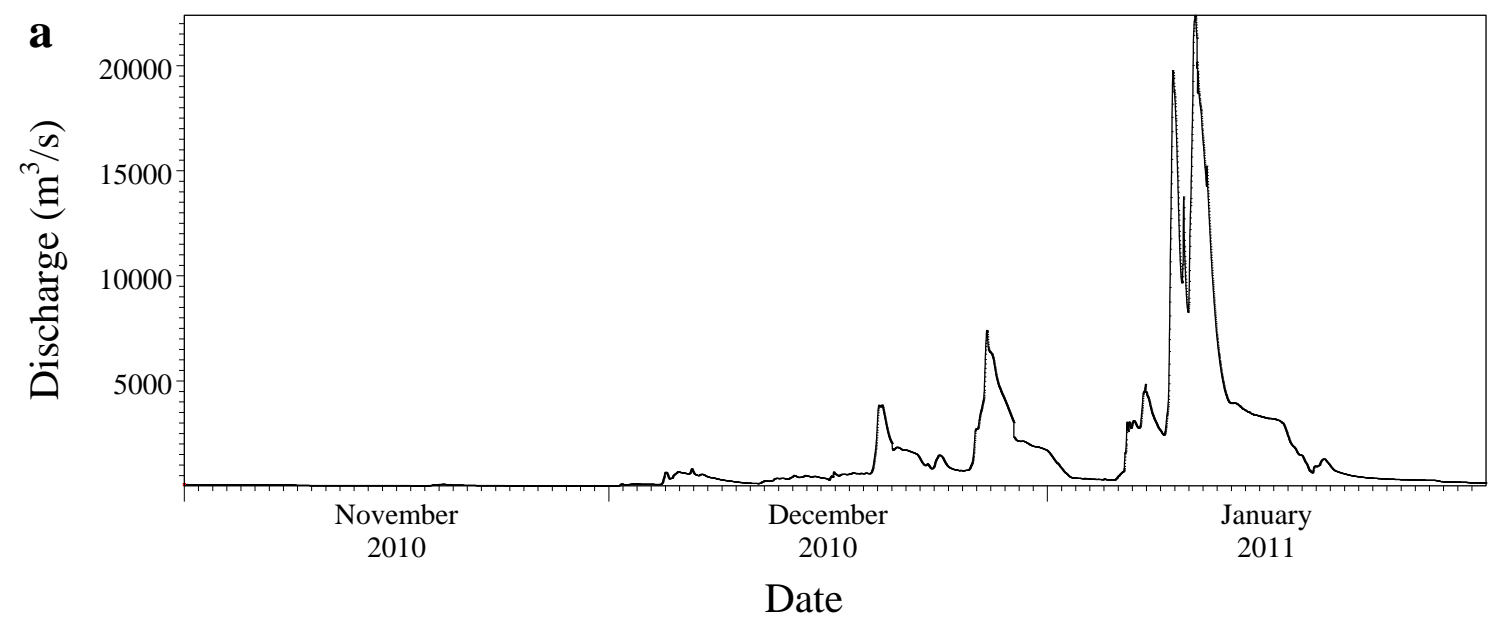

b

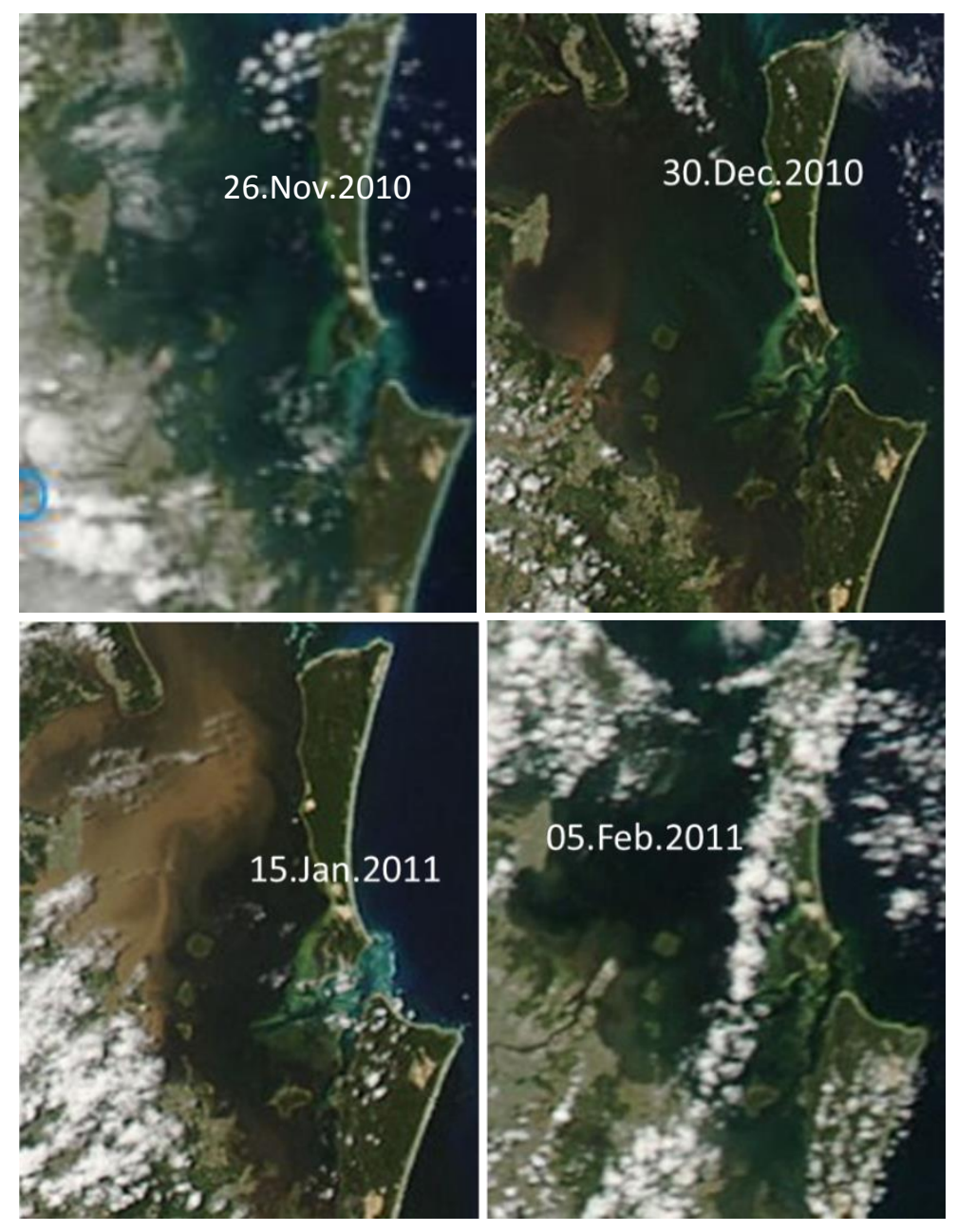



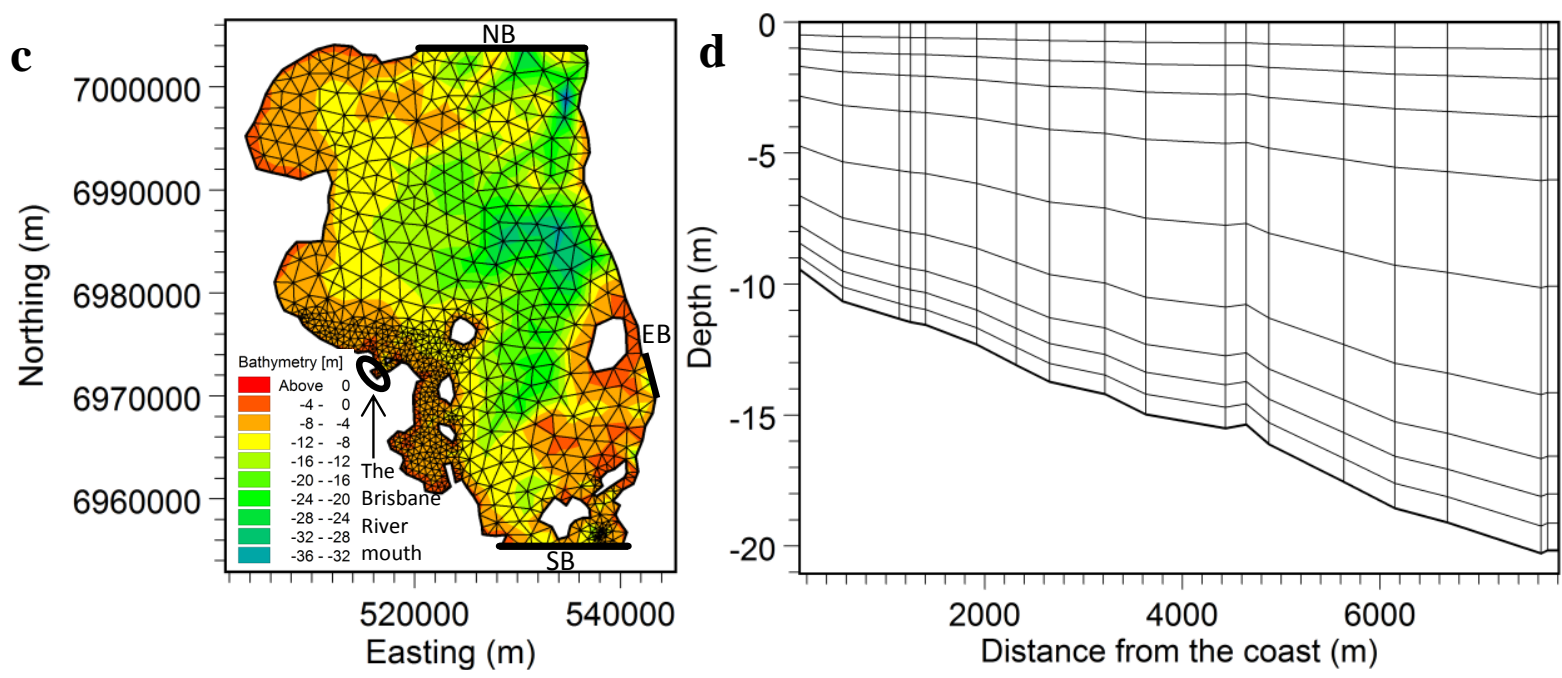

Fig. 2. (a) The Brisbane River 15-mintues discharge from December 2010 to January 2011 (Data Source: DERM Australia). (b)Satellite images of the Brisbane River and Moreton Bay (Source: MODIS Rapid Response System, NASA). The model meshes structure of Moreton Bay in (c) horizontal mesh and (d) vertical $\sigma$ layers, produced by DHI MIKE. Different color indicates the different water depths. 
a
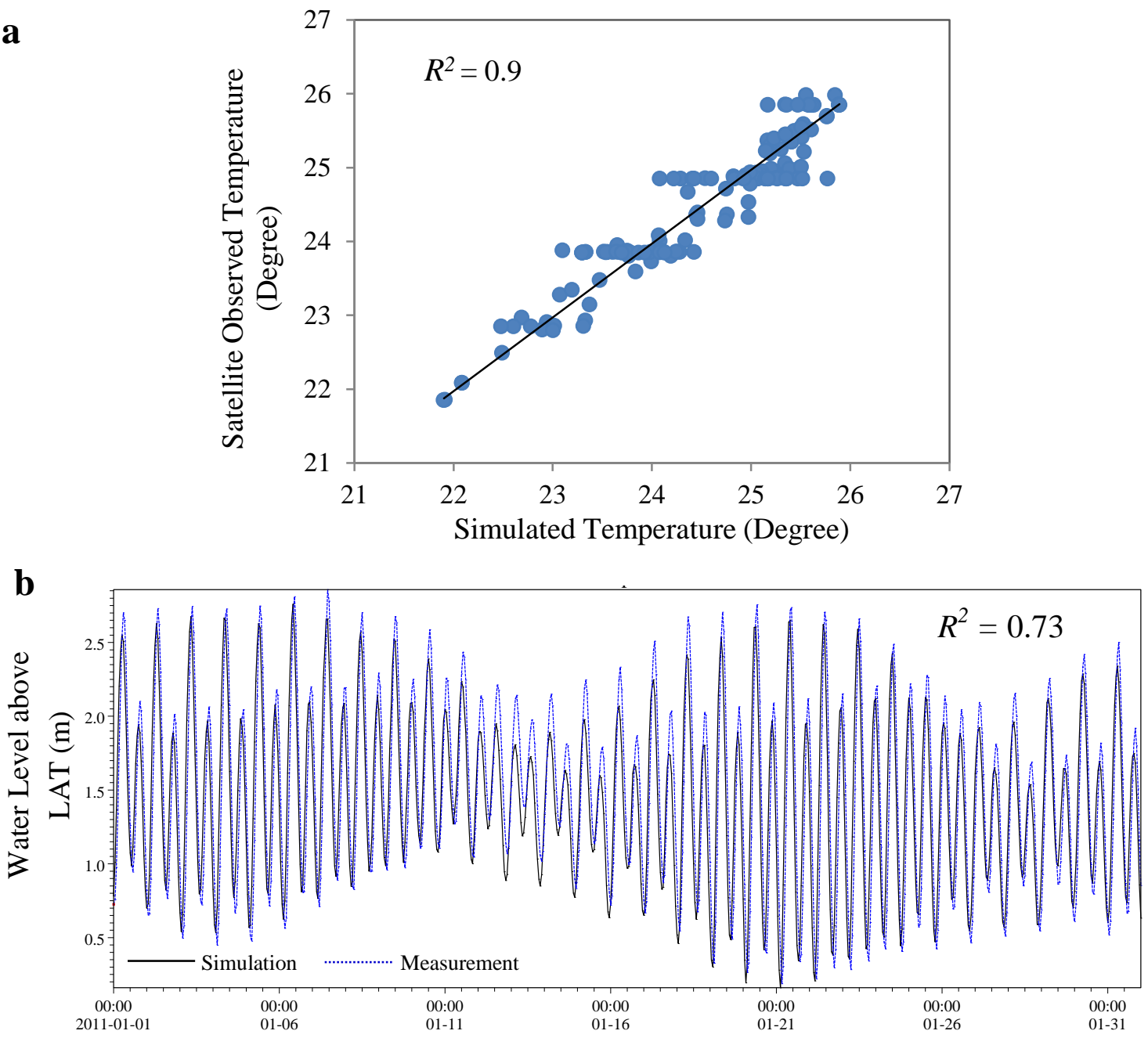

Date

c
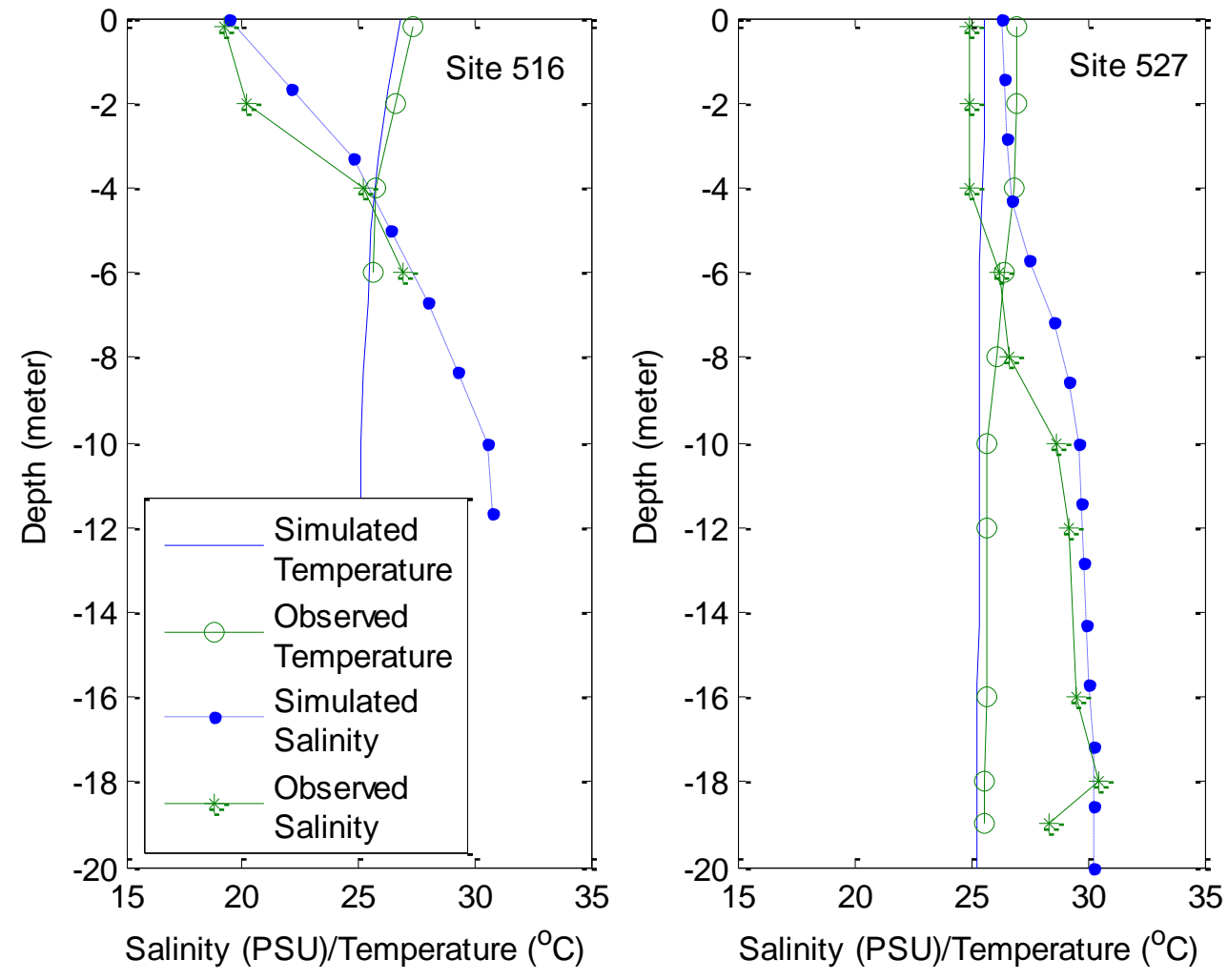


\section{d}
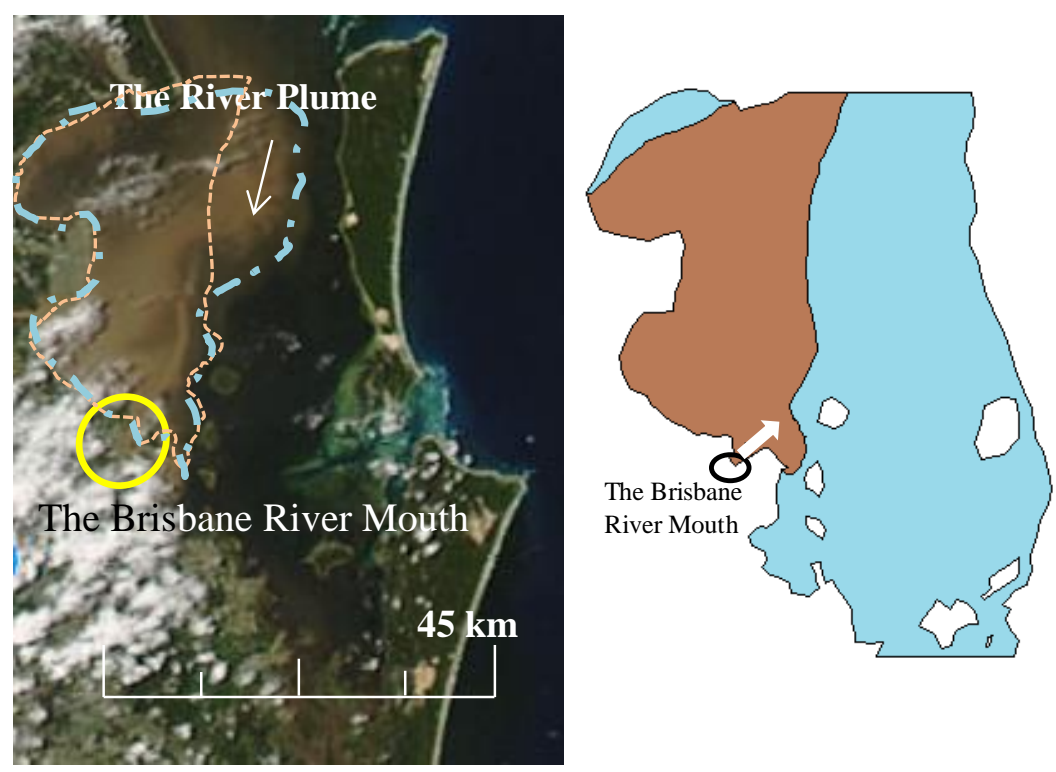

Fig. 3. Comparison of the simulated and satellite observed (a) sea surface temperatures on the $15^{\text {th }}$ January 2011 and (b) surface elevation at the Brisbane Bar in January 2011. (c) Simulated and observed salinity and temperature at different sites on the $19^{\text {th }}$ January 2011. (d) [Left panel] Satellite image of the Brisbane River flood plume in Moreton Bay on the $15^{\text {th }}$ January 2011(Source: MODIS Rapid Response System, NASA) and [right panel] that simulated by MIKE3. The edge of the satellite observed plume has been outlined by using a blue dash-dot line, while the edge of the simulated plume has been outlined by using a pink dash line. 
The plume on 21 December 2010
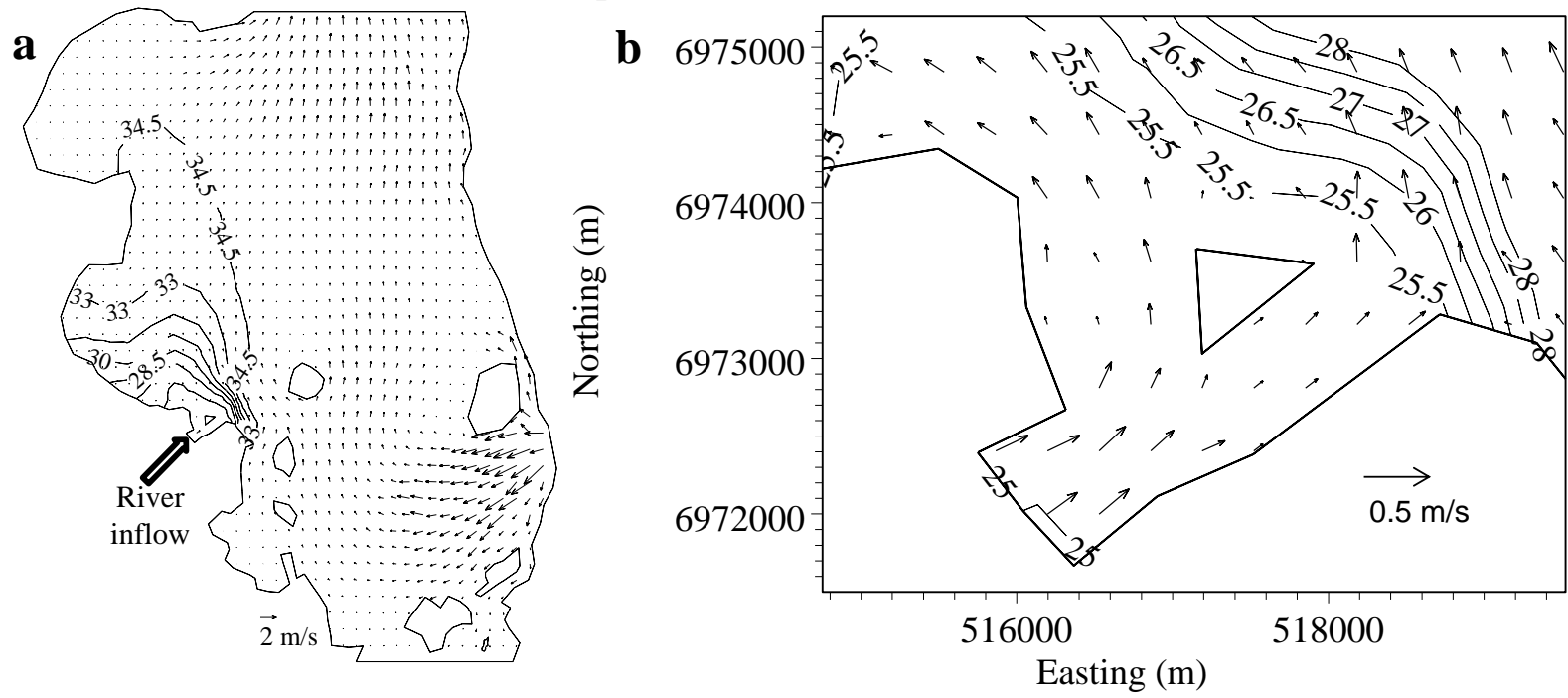

The plume on 12 January 2011

c

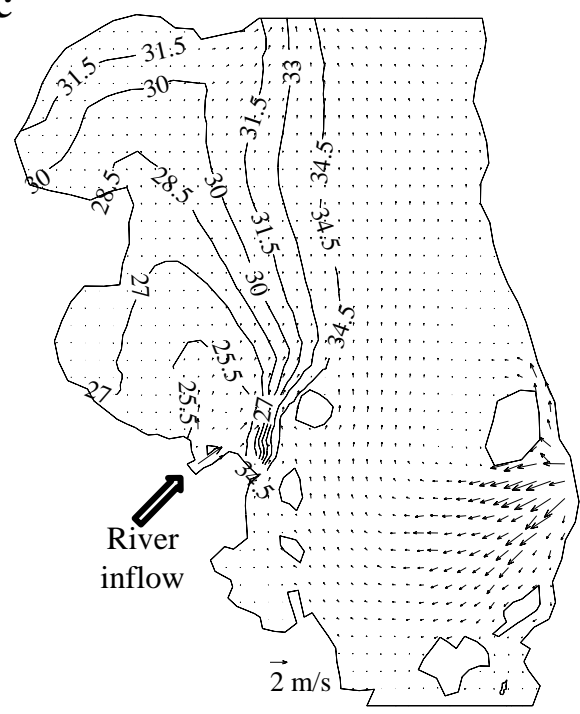

d

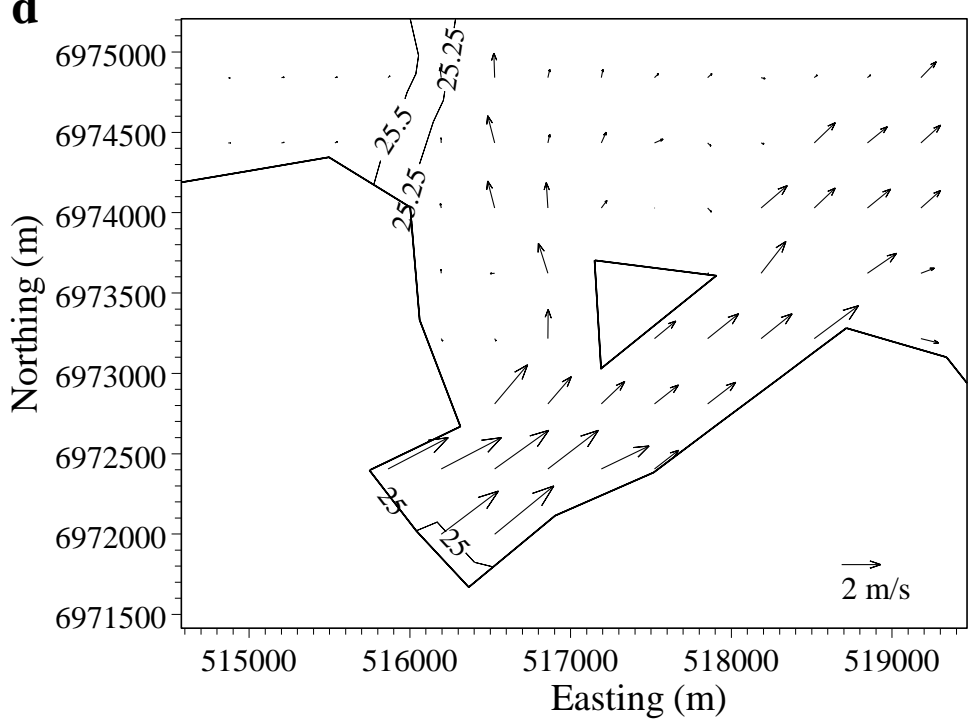

Fig. 4. Simulated the flood-driven plume water (< salinity of 34.5) in Moreton Bay on the $21^{\text {st }}$ December 2010 and the $12^{\text {th }}$ January 2011 respectively: (a) and (c) are the entire plume, and (b) and (d) are the plume near the river mouth. The contour lines are surface salinity and the vectors are surface current $(\mathrm{m} / \mathrm{s})$. 

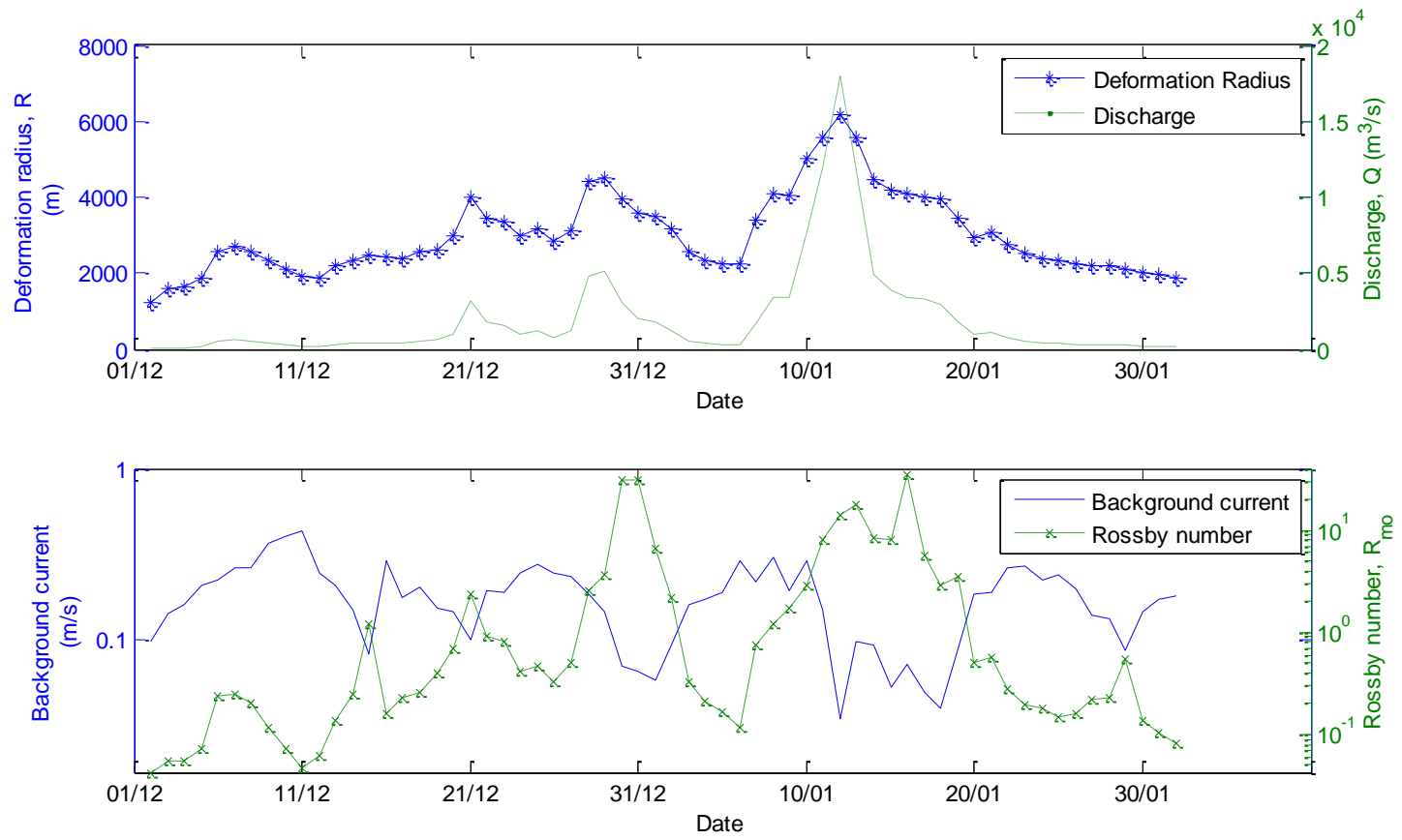

Fig. 5. (a) Deformation Radius of the river plume and the river discharge, and (b) Rossby number $R_{m o}$ and background current during the period of Queensland 2010-2011 flood event.
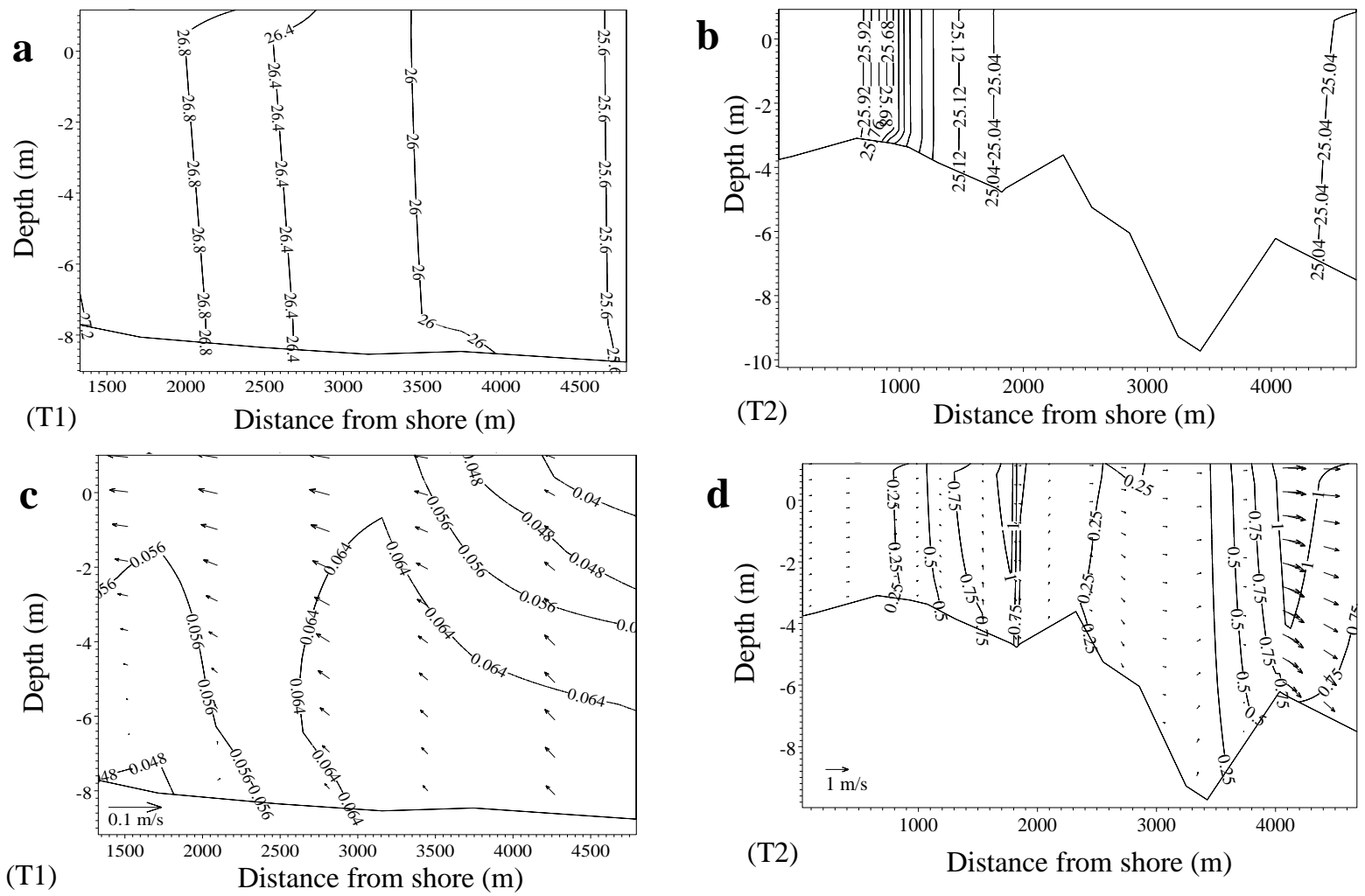


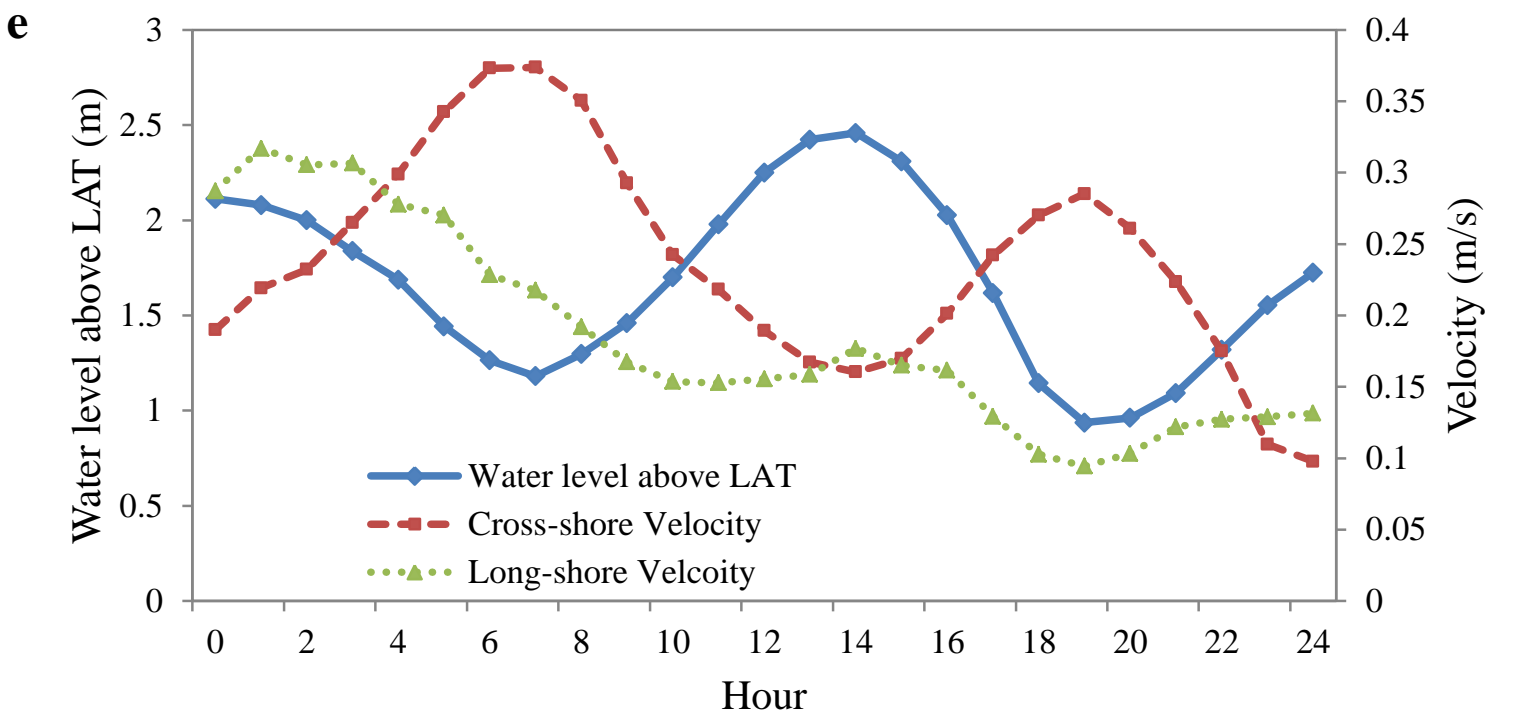

Fig. 6. Vertical distributions of salinity (in a and b) and velocity (in $\mathrm{c}$ and d) across Transect 1 (T1) and Transect 2 (T2) on the $12^{\text {th }}$ January 2011 respectively. The contour lines are salinity distribution (in a and b) and velocity condition in $\mathrm{m} / \mathrm{s}$ (in $\mathrm{c}$ and d). (e) Tidal elevation, crossshore and along shore velocities at P4 during a tidal cycle on 12 Jan. 2011. 
$\mathbf{a}$
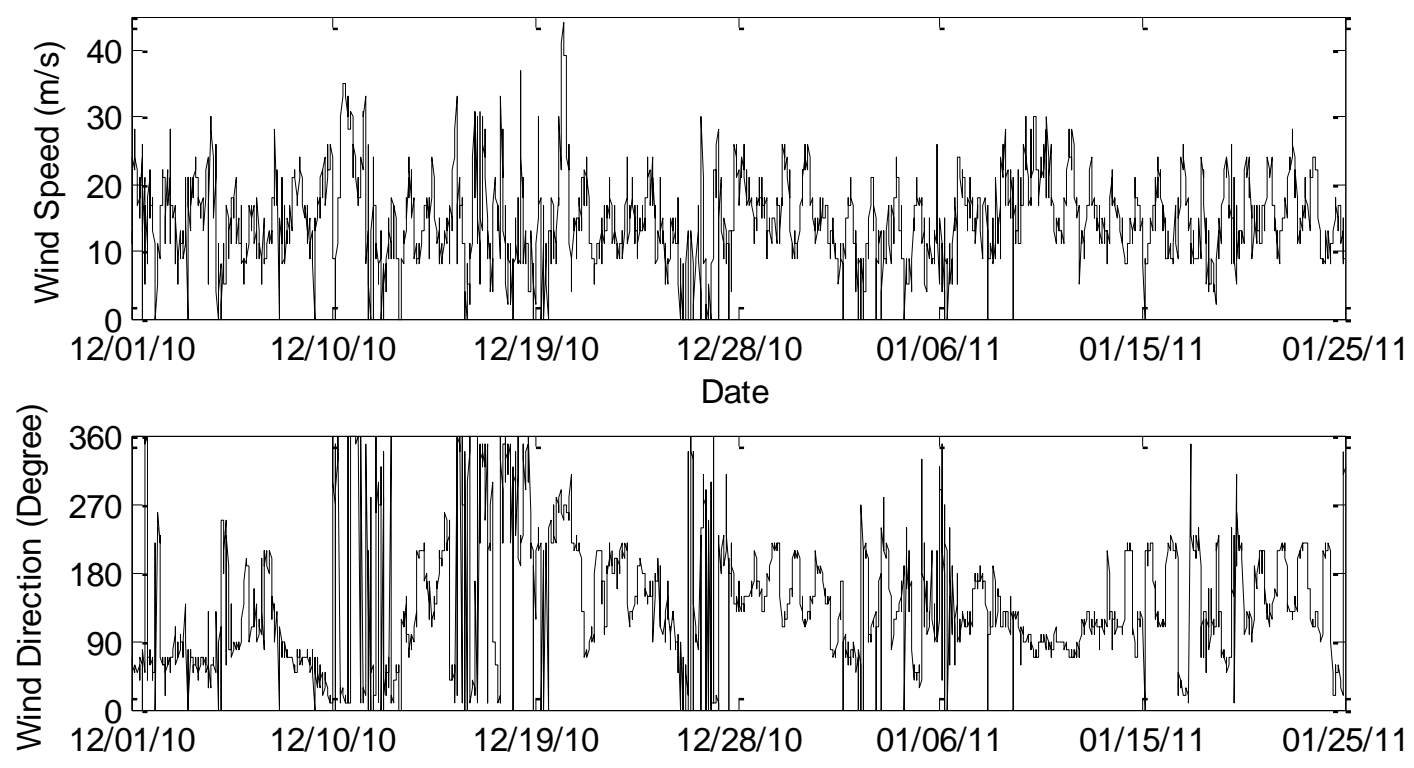

b

Date

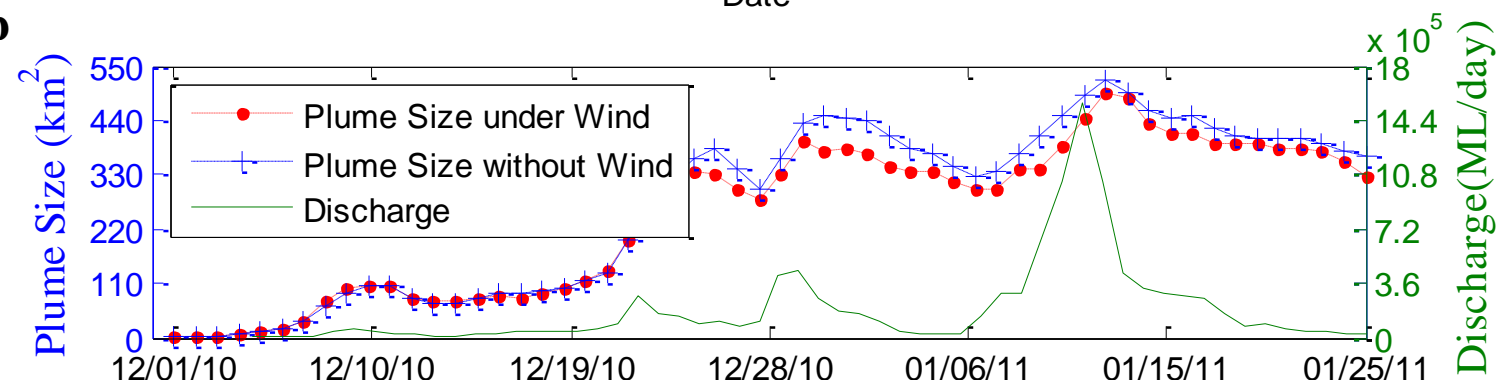

c

Date

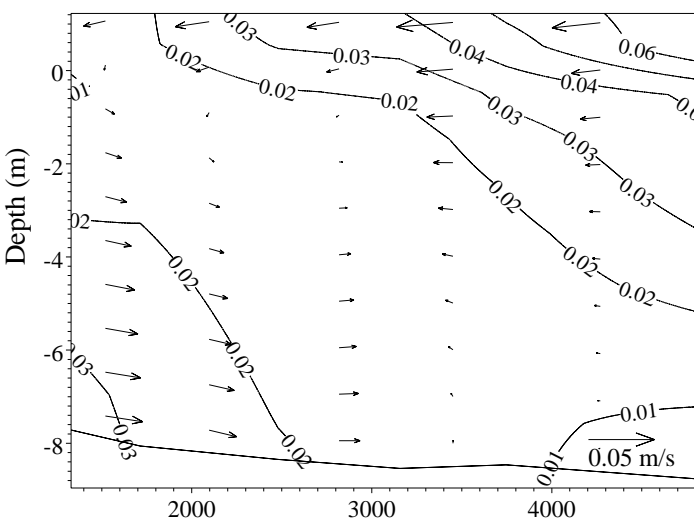

(T1)

Distance from shore (m)

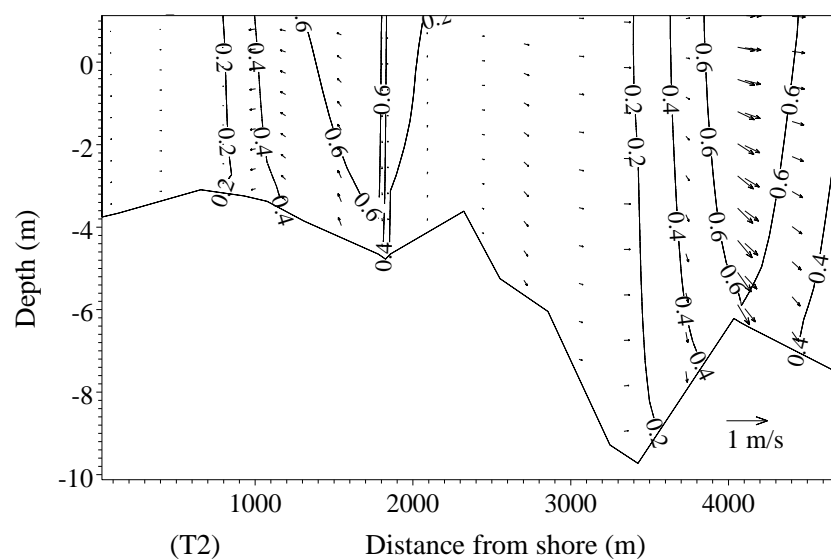

Fig. 7. (a) The wind speed and direction over Moreton Bay during this flood event (Data source: BOM Australia). (b) The Brisbane River daily discharge and its plume size with/without blowing wind in Queensland flood event in 2010-2011. (c) Vertical distributions of velocity across Transect 1 (T1) and Transect 2 (T2) on the $12^{\text {th }}$ January 2011 in Case 2. The contour lines and vectors are velocity condition in $\mathrm{m} / \mathrm{s}$. 

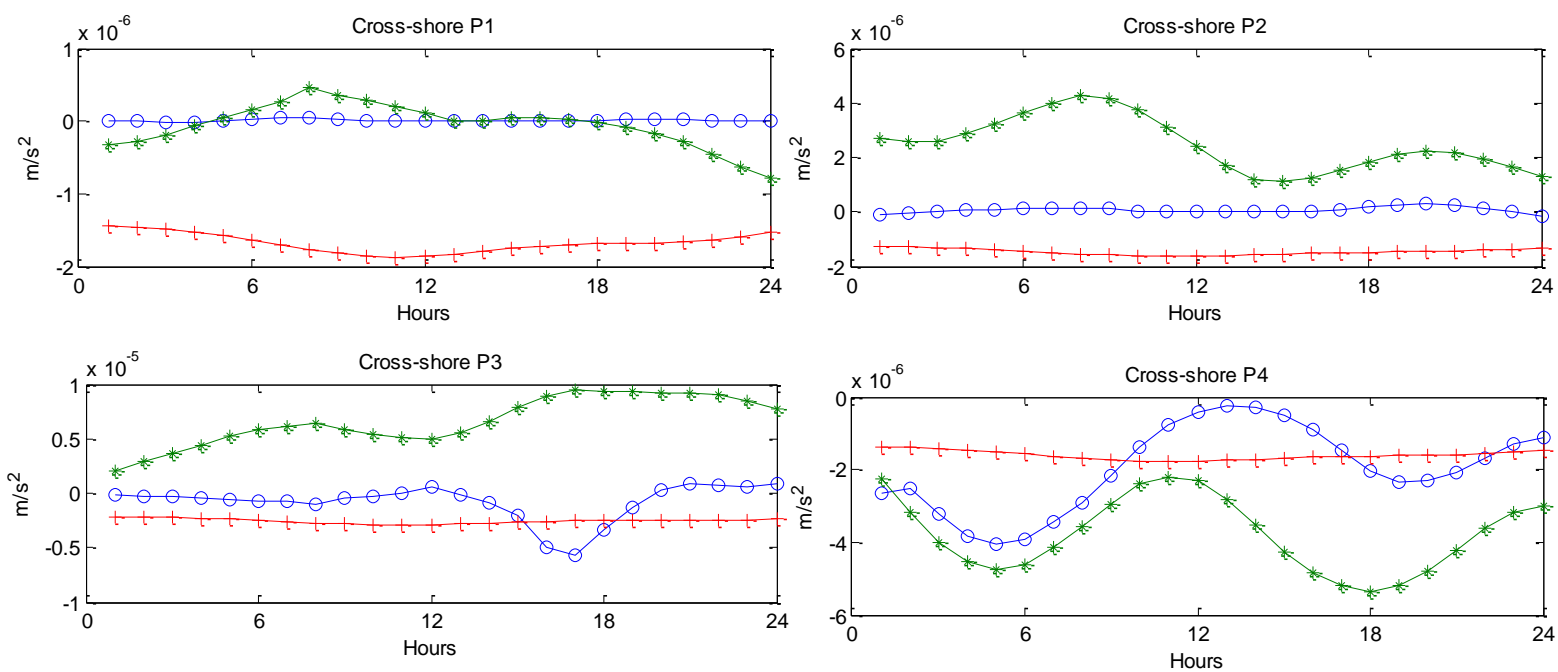

Convection term $\quad$ - Coriolis term $\div$ Wind stress term

Fig. 8. Estimation of the individual terms of cross-shore momentum at P1, P2 P3 and P4 (as marked in Fig. 1) on the $12^{\text {th }}$ January 2011.
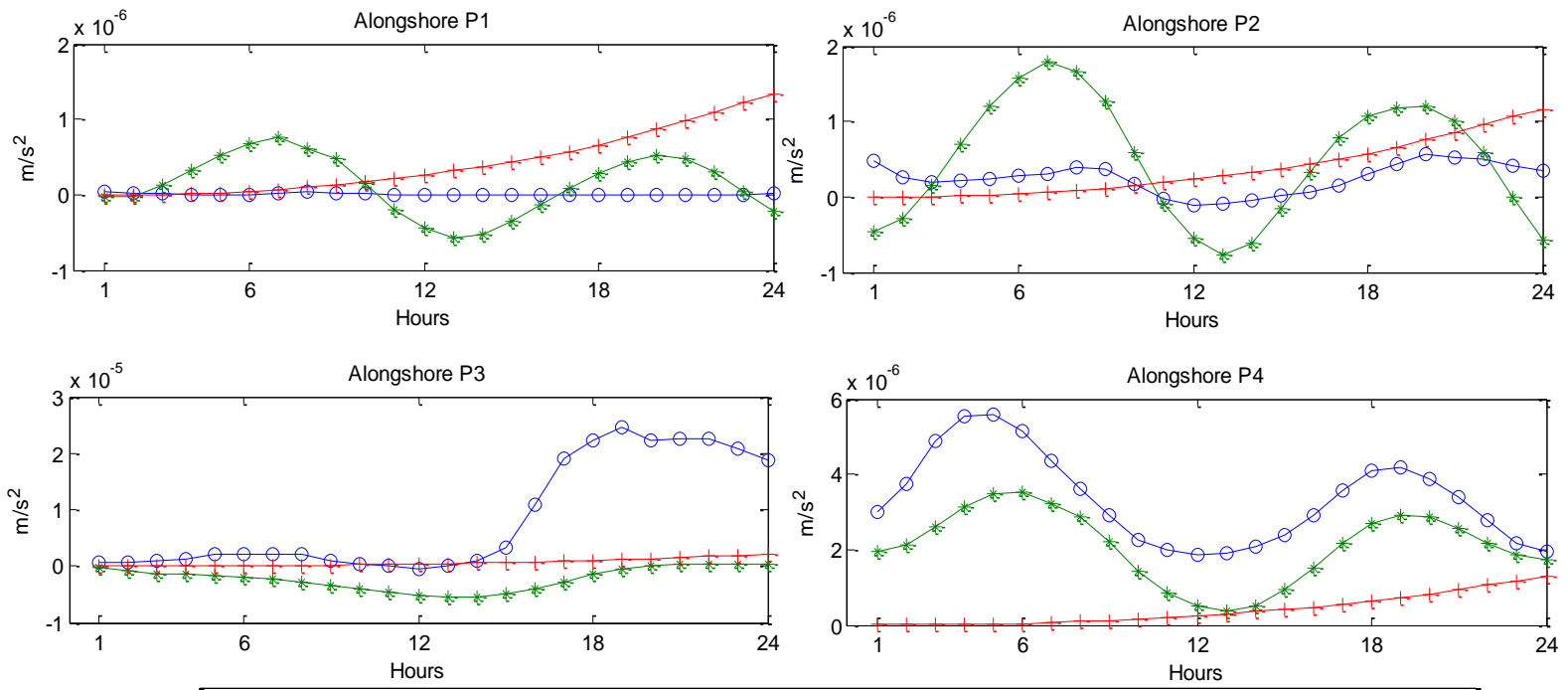

Convection term Coriolis term

Wind stress term

Fig. 9. Estimation of the individual terms of alongshore momentum at P1, P2 P3 and P4 (as marked in Fig 1) on the $12^{\text {th }}$ January 2011. 
$\mathbf{a}$

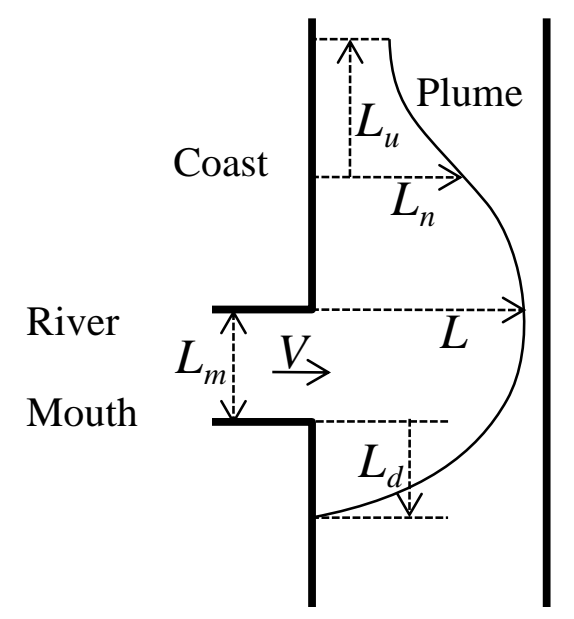

b

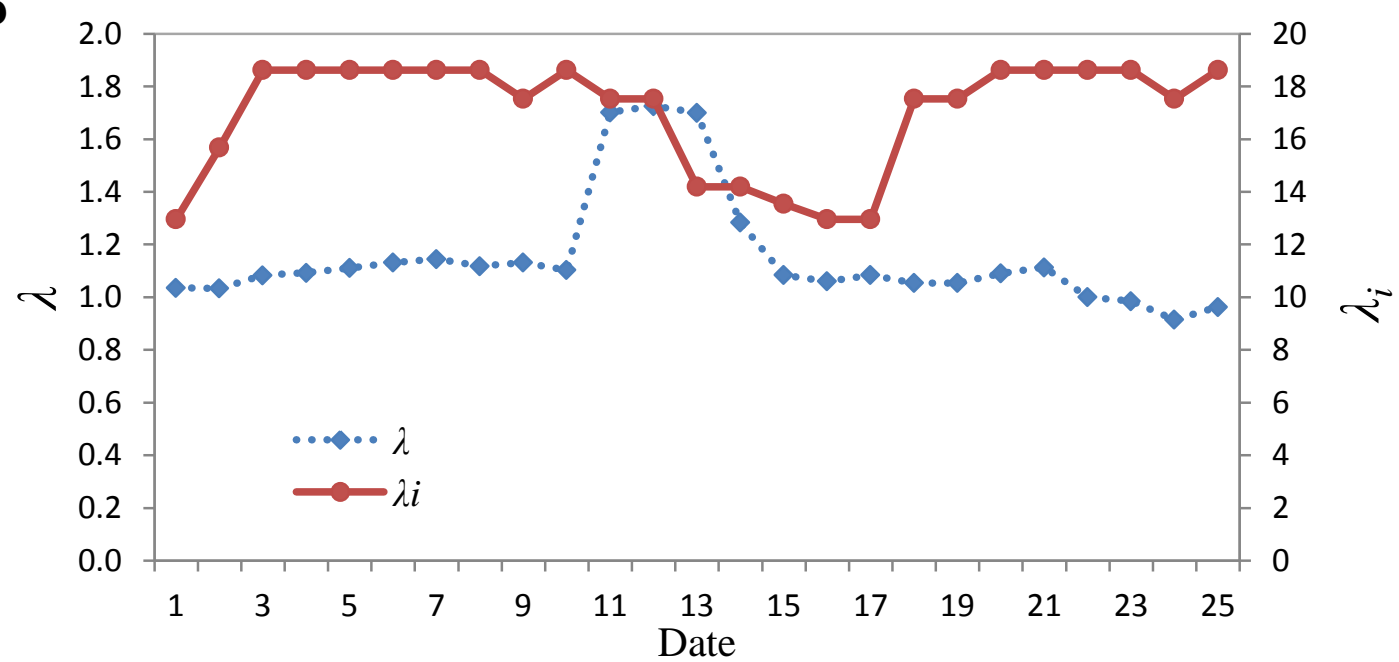

Fig. 10. (a) Four dimension parameters to characterise the plume. (b) The variations of two non-dimensional parameters, $\lambda_{i}$ and $\lambda$, from 1 to 25 January.
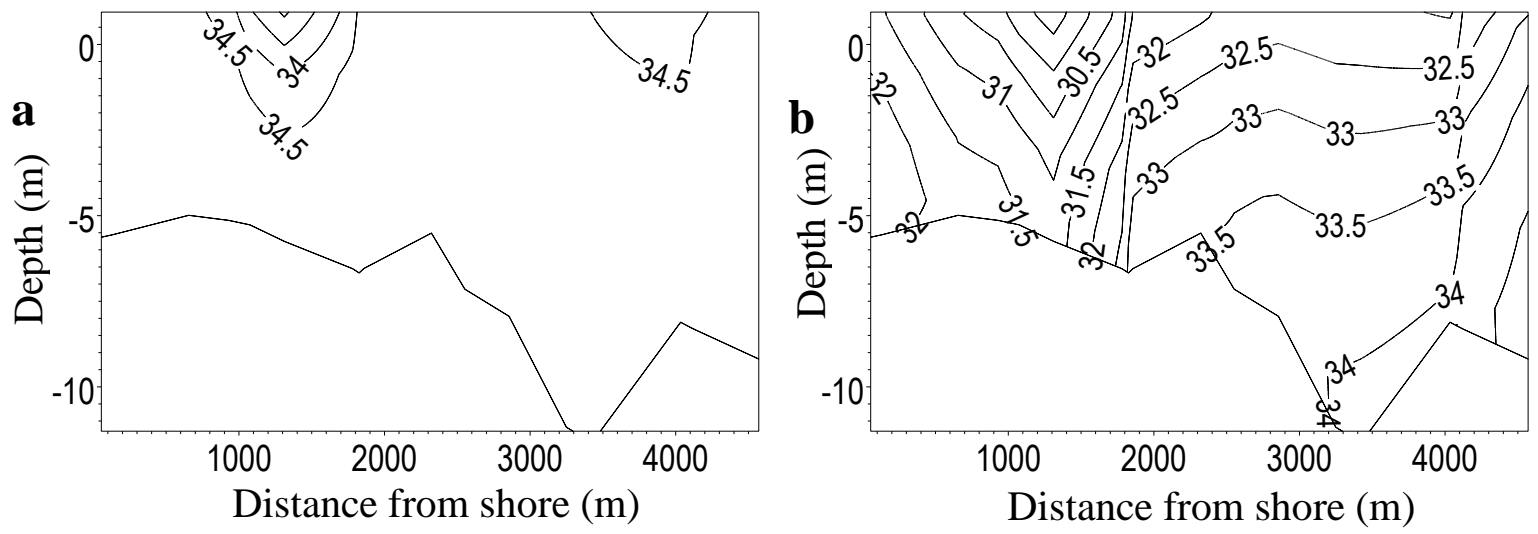

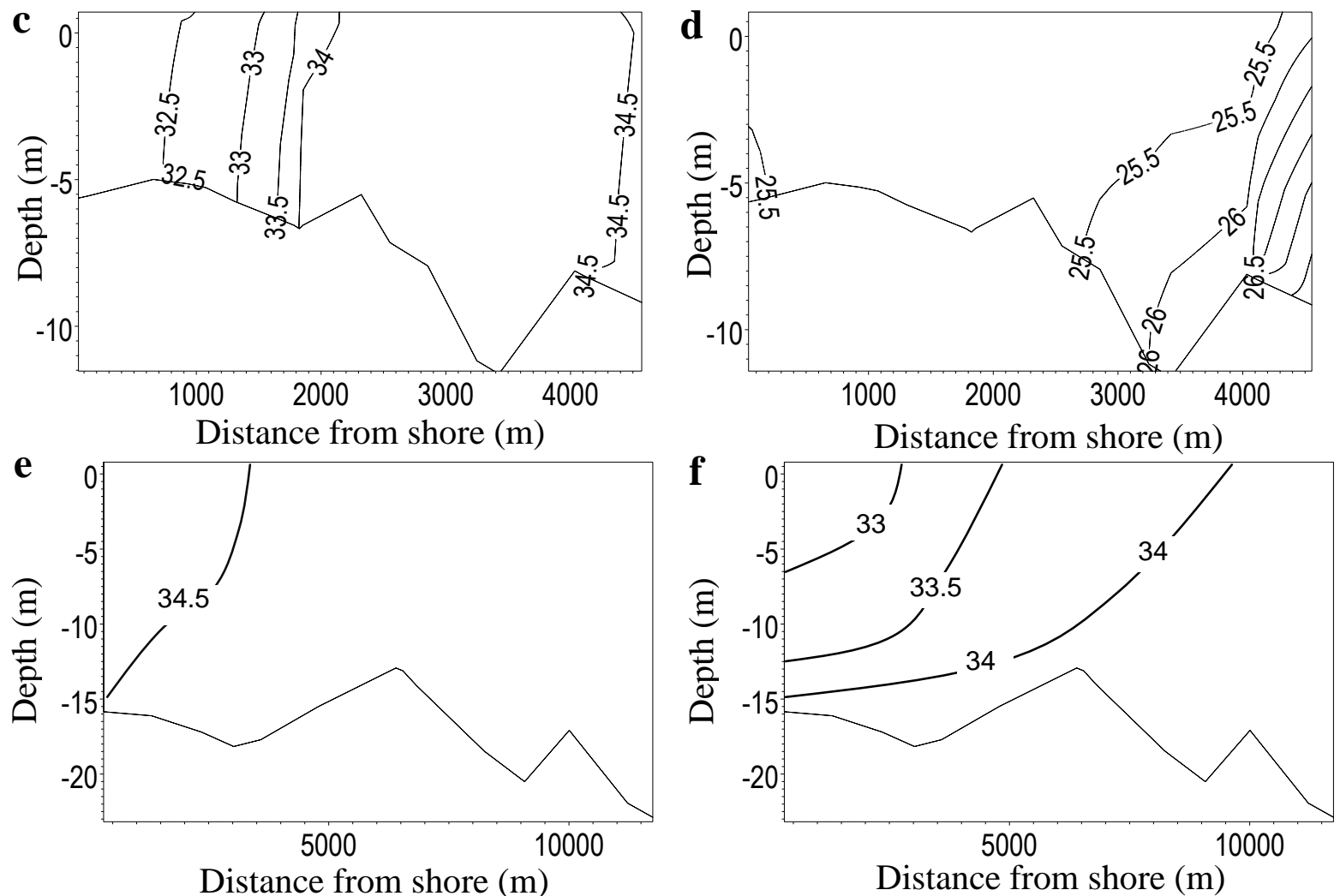

Fig. 11. Vertical profiles of the salinity distribution at Transect 2 on (a) 1, (b) 2, (c) 3 December 2010 and (d) 13 January 2011. Vertical profiles of the salinity distribution far away from the river mouth on (e) the $13^{\text {th }}$ and (f) the $18^{\text {th }}$ January, 2011. The contour lines are salinity distribution. 
Table 1 Comparisons of several extreme flood-driven plumes

\begin{tabular}{|c|c|c|c|c|c|}
\hline & & $\begin{array}{l}\text { The Eel River } \\
\text { plume } \\
\text { (Geyer et al., } \\
2000 \text { ) }\end{array}$ & $\begin{array}{c}\text { River plume } \\
\text { on the GBR } \\
\text { (King et al., } \\
2001 \text { ) }\end{array}$ & $\begin{array}{l}\text { The Brisbane } \\
\text { River plumes } \\
\text { (Yu et al., 2011) }\end{array}$ & $\begin{array}{l}\text { The Brisbane } \\
\text { River plumes }\end{array}$ \\
\hline \multicolumn{2}{|c|}{ Hemispheres } & Northern & Southern & Southern & Southern \\
\hline \multicolumn{2}{|c|}{ Flooding Date } & Jan 1998 & Jan 1981 & May 2009 & $\begin{array}{l}\text { Dec 2010- } \\
\text { Jan } 2011\end{array}$ \\
\hline \multicolumn{2}{|c|}{ Peak Discharge $\left(\mathrm{m}^{3} / \mathrm{s}\right)$} & $2000-3800$ & $8000-12000$ & $300-880$ & $5100-17000$ \\
\hline \multirow{2}{*}{$\begin{array}{l}\text { Wind } \\
\text { conditions }\end{array}$} & Speed $(\mathrm{m} / \mathrm{s})$ & 10 & 18 & 10 & 18 \\
\hline & Direction & $\mathrm{S}$ & SE & $\mathrm{S}$ & SSE \\
\hline \multirow{3}{*}{$\begin{array}{l}\text { Dimensions } \\
\text { of the } \\
\text { Plume }\end{array}$} & Width (km) & 5 & 20 & 3.6 & 10 \\
\hline & Length $(\mathrm{km})$ & 7 & 150 & 5.2 & 29 \\
\hline & Depth (m) & 50 & 30 & 11 & 15 \\
\hline \multicolumn{2}{|c|}{$\begin{array}{l}\text { Estimated residual time } \\
\text { of the plume (days) }\end{array}$} & - & - & 0.4 & 20 \\
\hline
\end{tabular}

